\title{
The Search for New Anticonvulsants in a Group of (2,5-Dioxopyrrolidin-1-yl)(phenyl)Acetamides with Hybrid Structure-Synthesis and In Vivo/In Vitro Studies
}

\author{
Michał Abram ${ }^{1}{ }^{(D}$, Marcin Jakubiec ${ }^{1}$, Anna Rapacz ${ }^{2}$, Szczepan Mogilski ${ }^{2}$, \\ Gniewomir Latacz ${ }^{3}{ }^{(D}$, Rafał M. Kamiński ${ }^{1}$ and Krzysztof Kamiński ${ }^{1, *(D)}$ \\ 1 Department of Medicinal Chemistry, Faculty of Pharmacy, Jagiellonian University Medical College, \\ Medyczna 9, 30-688 Cracow, Poland; michal.abram@doctoral.uj.edu.pl (M.A.); \\ marcin.jakubiec@doctoral.uj.edu.pl (M.J.); rafa1.kaminski@uj.edu.pl (R.M.K.) \\ 2 Department of Pharmacodynamics, Faculty of Pharmacy, Jagiellonian University Medical College, \\ Medyczna 9, 30-688 Cracow, Poland; a.rapacz@uj.edu.pl (A.R.); szczepan.mogilski@uj.edu.pl (S.M.) \\ 3 Department of Technology and Biotechnology of Drugs, Faculty of Pharmacy, Jagiellonian University \\ Medical College, Medyczna 9, 30-688 Cracow, Poland; gniewomir.latacz@uj.edu.pl \\ * Correspondence: k.kaminski@uj.edu.pl; Tel.: +48-12-620-54-59
}

Received: 15 October 2020; Accepted: 18 November 2020; Published: 20 November 2020

\begin{abstract}
Epilepsy belongs to the most common and debilitating neurological disorders with multifactorial pathophysiology and a high level of drug resistance. Therefore, with the aim of searching for new, more effective, and/or safer therapeutics, we discovered a focused series of original hybrid pyrrolidine-2,5-dione derivatives with potent anticonvulsant properties. We applied an optimized coupling reaction yielding several hybrid compounds that showed broad-spectrum activity in widely accepted animal seizure models, namely, the maximal electroshock (MES) test and the psychomotor $6 \mathrm{~Hz}(32 \mathrm{~mA})$ seizure model in mice. The most potent anticonvulsant activity and favorable safety profile was demonstrated for compound 30 (median effective dose $\left(E_{50}\right) \mathrm{MES}=45.6 \mathrm{mg} / \mathrm{kg}$, $\mathrm{ED}_{50} 6 \mathrm{~Hz}(32 \mathrm{~mA})=39.5 \mathrm{mg} / \mathrm{kg}$, median toxic dose $\left(\mathrm{TD}_{50}\right)$ (rotarod test) $\left.=162.4 \mathrm{mg} / \mathrm{kg}\right)$. Anticonvulsant drugs often show activity in pain models, and compound $\mathbf{3 0}$ was also proven effective in the formalin test of tonic pain, the capsaicin-induced pain model, and the oxaliplatin (OXPT)-induced neuropathic pain model in mice. Our studies showed that the most plausible mechanism of action of $\mathbf{3 0}$ involves inhibition of calcium currents mediated by Cav1.2 (L-type) channels. Importantly, $\mathbf{3 0}$ revealed high metabolic stability on human liver microsomes, negligible hepatotoxicity, and relatively weak inhibition of CYP3A4, CYP2D6, and CYP2C9 isoforms of cytochrome P450, compared to reference compounds. The promising in vivo activity profile and drug-like properties of compound $\mathbf{3 0}$ make it an interesting candidate for further preclinical development.
\end{abstract}

Keywords: hybrid molecules; pyrrolidine-2,5-dione; anticonvulsant activity; antinociceptive activity; in vitro binding/functional studies; absorption, distribution, metabolism, excretion, toxicity (ADME-Tox) properties

\section{Introduction}

Epilepsy remains one of the least understood neurological diseases with complex and multifactorial pathogenesis. It is estimated that about 50 million people worldwide suffer from this disease, making it the second most common neurological disorder after stroke [1,2]. Despite unquestionable advances in epilepsy research, nearly $30 \%$ of patients still experience uncontrolled, debilitating seizures [3]. 
Furthermore, even if the desired therapeutic effect is achieved, most of the available antiepileptic drugs (AEDs) often produce problematic side effects, e.g., memory impairment, diminished attention, and executive function or somnolence, due to their unspecific inhibitory influence on the central nervous system (CNS) [4]. In recent years, several new AEDs such as levetiracetam, brivaracetam, lacosamide, or perampanel have been introduced into the pharmacotherapy of seizures. However, despite their efficacy in several types of epilepsy, as well as better tolerance by patients, compared to older AEDs, they have not resolved the problem of drug-resistant epilepsy [5].

The multitargeted compounds which usually show broad pharmacological activity seem to be especially relevant for diseases with multifactorial origin and conditions with a high risk of drug resistance, such as depression, cancer, Parkinson's disease, Alzheimer's disease, neuropathic pain, and epilepsy [6-9]. Substances characterized by multitarget activity typically include hybrid or chimeric structures that contain several pharmacophores merged as one chemical scaffold [10]. This "multistructural" chemical composition gives the possibility of interaction with different biological targets potentially translating into better therapeutic efficacy. The most essential advantages of multitargeted compounds vs. combination therapies, which are usually required in severe diseases, include reduced risk of drug-drug interactions, limited side effects, and better patient compliance [11].

Our previous studies proved that the application of a molecular hybridization strategy may result in anticonvulsants with a wide spectrum of activity in different animal models of epilepsy [9,12-15]. Impotently, a number of such molecules also displayed potent antinociceptive activity in the in vivo studies. These compounds were designed as hybrid molecules on the basis of the pyrrolidine-2,5-dione core ring that merges structural fragments of known and clinically used AEDs, namely, ethosuximide (ETX), levetiracetam (LEV), and lacosamide (LCS). The in vivo data revealed that the several hybrid substances showed distinctly more potent and/or wider anticonvulsant efficacy compared to each of the aforementioned AEDs. In consequence, the hybrid compounds reported previously $[9,12-15]$ were active in all three seizure models, i.e., the maximal electroshock (MES), subcutaneous pentylenetetrazole ( $s c$ PTZ), and the psychomotor $6 \mathrm{~Hz}(32 \mathrm{~mA})$ seizure model. In contrast, ETX protected mice only in the scPTZ model, while LCS was active in the MES and $6 \mathrm{~Hz}$ seizure models; lastly, LEV showed efficacy only in the $6 \mathrm{~Hz}$ seizure model. Thus, it is postulated that the proposed multifunctional compounds may be potentially effective in a broad range of human epilepsies characterized by tonic-clonic seizures, absence seizures, and importantly the most common focal seizures that affect more than $50 \%$ patients [16].

The MES test is still recognized as one of the most useful experimental tools for early identification of new AEDs, and it is recognized as an animal model of tonic-clonic seizures in human epilepsy [17]. The structure-activity relationship analysis of known AEDs that show potent protection in the MES test revealed that the majority of these compounds contain two aromatic rings in their structure (e.g., lamotrigine, phenytoin, or perampanel; see Figure 1). Therefore, we aimed to obtain new hybrid compounds with increased protection in the MES test; we report herein a series of new 2-(2,5-dioxopyrrolidin-1-yl)-2-phenylacetamides. These molecules were designed as analogues of previously described 2-(2,5-dioxopyrrolidin-1-yl)-2-alkylacetamides with an additional benzene ring attached to the side methyl group (marked in green, Figure 1). It should be stressed here that the aforementioned 2-(2,5-dioxopyrrolidin-1-yl)-2-alkylacetamides displayed only weak activity in the MES test $[12,13]$. Furthermore, we also hypothesized that the introduction of an additional aromatic moiety resulting in an increased lipophilicity may afford better blood-brain barrier penetration and more potent activity. As the amine function, we introduced unsubstituted phenylamine, benzylamine, phenylethylamine, and phenylpropylamine or their selected derivatives containing exclusively electron-withdrawing atoms or groups that appeared to be essential for anticonvulsant activity on the basis of previous results $[12,13]$. The design process and the general structure of the compounds described in the current paper are shown in Figure 1. For the selected most potent anticonvulsant compounds, we also assessed their antinociceptive properties in vivo, as well as 
performed mechanism-of-action studies and characterized basic absorption, distribution, metabolism, excretion, toxicity (ADME-Tox) properties in vitro.

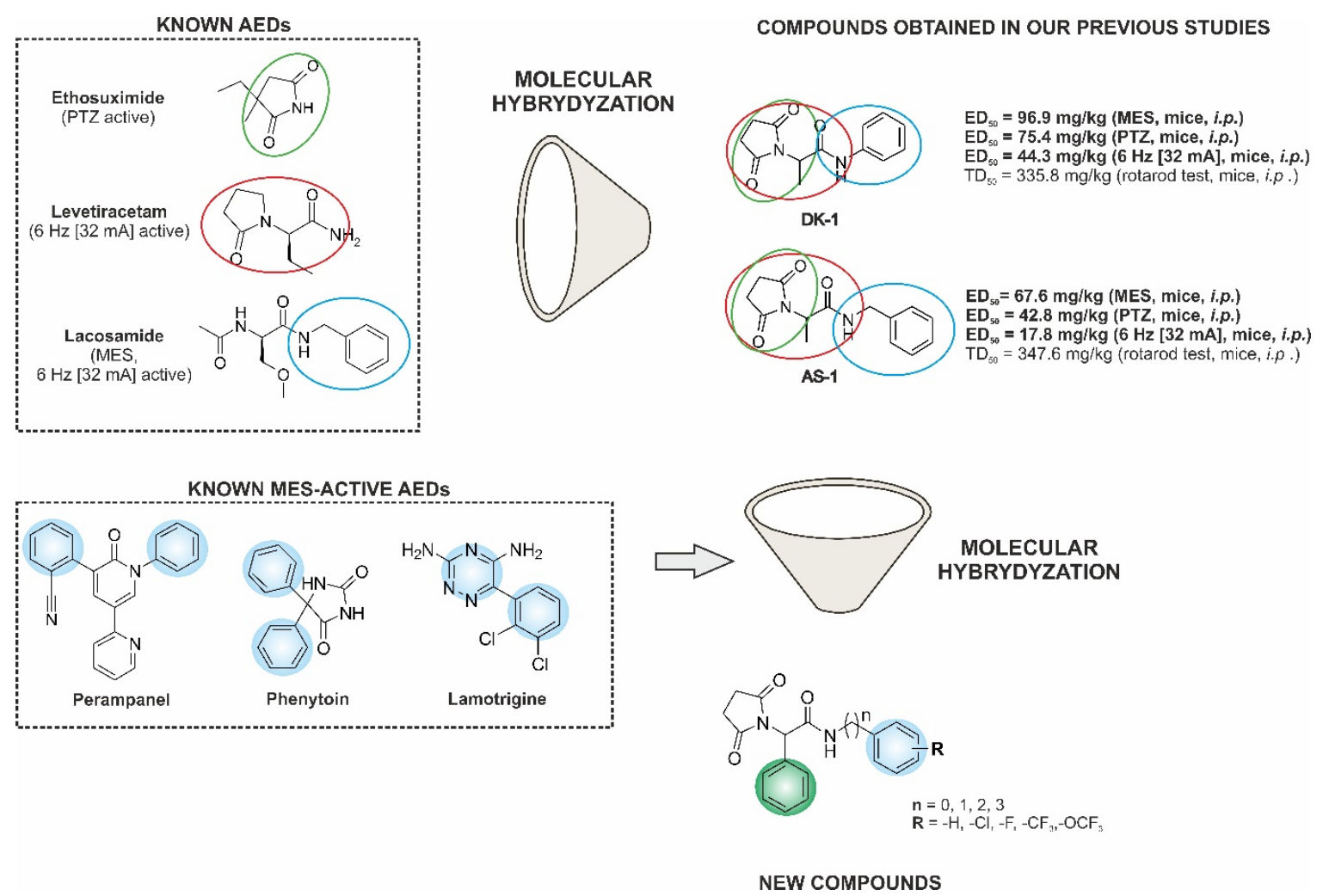

Figure 1. Design and general structure of hybrid 2-(2,5-dioxopyrrolidin-1-yl)-2-phenylacetamide derivatives (the main modification site is marked in green).

\section{Results and Discussion}

\subsection{Chemistry}

Compounds 3-31 were synthesized using a multistep procedure according to Scheme 1. First, succinamic acid (1) was obtained by reacting equimolar amounts of commercially available succinic anhydride with DL-phenylglycine, and this reaction was carried out in $70^{\circ} \mathrm{C}$ in acetic acid. Succinamic acid (1) was obtained as a solid substance after wash up with diethyl ether and was used without future purification. Next, the hexamethyldisilazane (HMDS)-promoted cyclization reaction of $\mathbf{1}$, performed in benzene according to previously reported method [18], yielded monocarboxylic acid (2). The final compounds 3-31 were obtained by coupling of intermediate 2 with respective primary amine derivatives in the presence of carbonyldiimidazole (CDI) as the coupling reagent in dry dimethylformamide (DMF) as a solvent. This reaction was carried out at room temperature, and its progress was monitored by high-performance liquid chromatography (HPLC) (completion at $\sim 24 \mathrm{~h}$ ). Final compounds were purified by flash column chromatography and were obtained as solid substances, followed by concentration of organic solvents under reduced pressure. The target hybrid compounds were obtained with good yield (62.9-79.2\%). The structures of intermediates and final molecules were confirmed by ${ }^{1} \mathrm{H}-\mathrm{NMR},{ }^{13} \mathrm{C}-\mathrm{NMR}$ (selected molecules), and/or LC-MS spectral analysis. Elemental analyses $(\mathrm{C}, \mathrm{H}$, and $\mathrm{N})$ were performed for all the final compounds synthesized. The detailed physicochemical and spectral data are summarized in Section 3. 


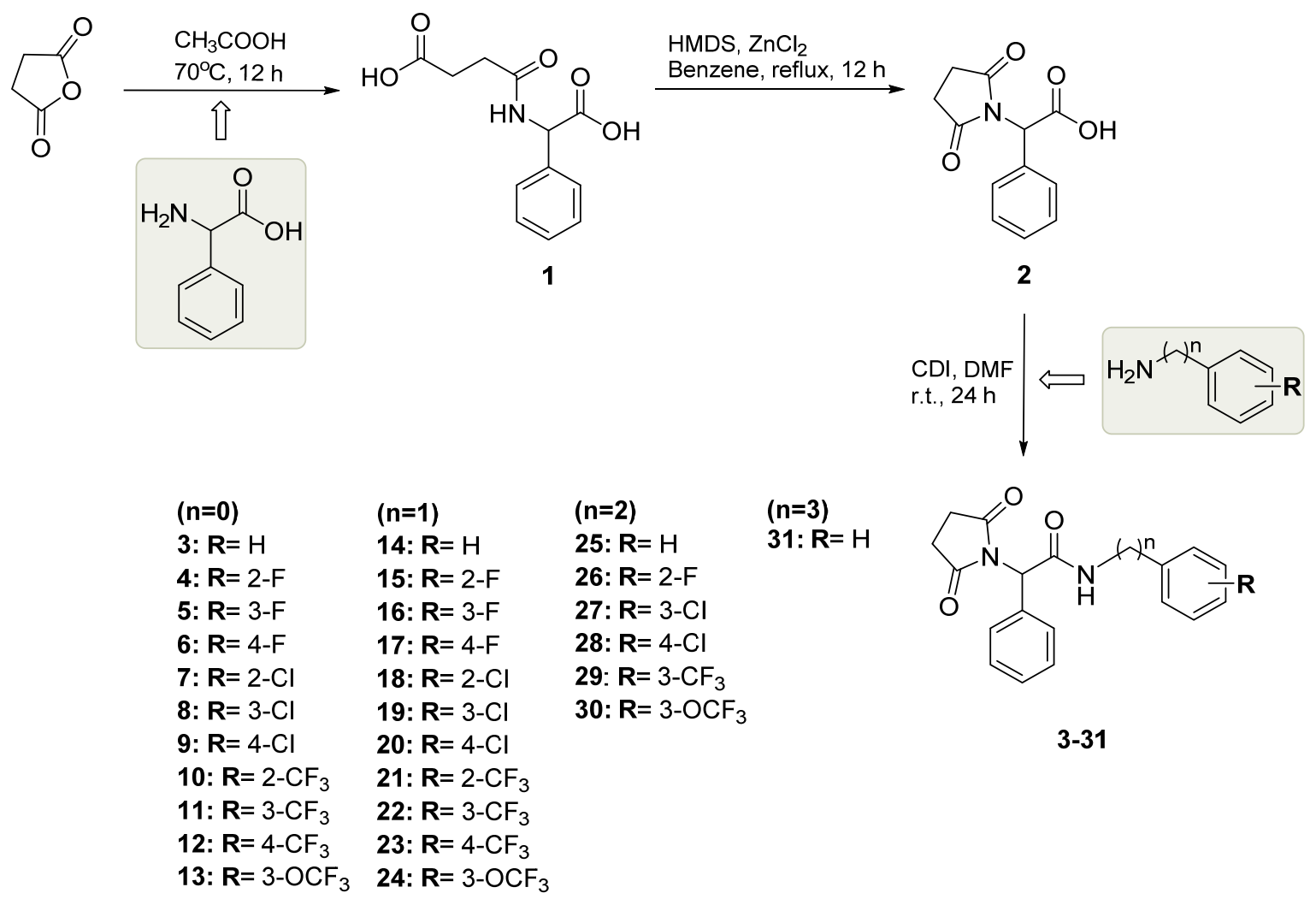

Scheme 1. Synthesis of intermediates 1, 2 and target compounds 3-31.

In the case of compounds $\mathbf{2 4}$ and $\mathbf{3 0}$, the respective noncommercial primary amines $\mathbf{A} \mathbf{1}$ and $\mathbf{A 2}$ were synthesized prior to the coupling reaction. Amines A1 and $\mathbf{A} \mathbf{2}$ were obtained via reduction of commercially available nitriles using the solid $\mathrm{LiAlH}_{4}$ as a reductive agent (Scheme S1, Supplementary Materials). At first, the tetrahydrofuran (THF) solution of the given nitrile derivative was added dropwise to the suspension of $\mathrm{LiAlH}_{4}$ in anhydrous THF at $0{ }^{\circ} \mathrm{C}$. Afterward, the reaction mixture was stirred at room temperature for additional $6 \mathrm{~h}$. The progress of the reaction was monitored by HPLC. After the reaction was completed, the excess of $\mathrm{LiAlH}_{4}$ was neutralized by addition of $10 \% \mathrm{NaOH}$ at $0{ }^{\circ} \mathrm{C}$. Next, the reaction mixture was filtered through Celite 545 (Merck, Darmstadt, Germany), and the obtained solution was extracted with dichloromethane (DCM). The organic layer was dried over anhydrous $\mathrm{Na}_{2} \mathrm{SO}_{4}$, and then evaporated to dryness. Amines $\mathbf{A 1}$ and $\mathbf{A 2}$ were used to further reactions without purification. The detailed synthetic procedure and the physicochemical and spectral data for $\mathbf{A} 1$ and $\mathbf{A} 2$ are described in the Supplementary Materials.

\subsection{Anticonvulsant Activity}

Empirical screening in animal models of human epileptic seizures is still recognized as a standard and effective paradigm in the discovery and development of new anticonvulsants [19]. Notably, this approach enabled identification of nearly all commercially launched AEDs so far. It should also be stressed that the screening approach enables detection of both substances acting on molecular targets that are well known for existing anticonvulsants, as well as compounds with new and undefined modes of action. In consequence, all final compounds 3-31 were initially evaluated in the MES test, which is an experimental model of tonic-clonic epilepsy [17]. This test, as a mechanism-independent animal seizure model, detects compounds capable of preventing the spread of seizures when all neurons in the brain are maximally active. It is noteworthy that the MES test is still recognized as the most useful preclinical seizure model and, hence, is widely employed during the early identification of new AED candidates. Importantly, the MES test may also help to find substances with unique mechanism of action [20]. 
Bearing in mind the aforementioned facts, all final substances were initially studied in the MES test after intraperitoneal (i.p.) administration at a fixed dose of $100 \mathrm{mg} / \mathrm{kg}$ in mice (in a group consisting of four animals). The protection effect against MES seizures was observed at $0.5 \mathrm{~h}$ post intraperitoneal (i.p.) injection. The pretreatment time was chosen on the basis of our previous experimentations [9,12-15]. According to the screening data (Tables S1-S3, Supplementary Materials), at least $50 \%$ protection, which was considered as satisfactory, was demonstrated for compounds 3, 4, 6, 8, 9 (anilinamide derivatives), 14, 19, 21, 22, 24 (benzylamide derivatives), 25, 27-30 (phenyletylamide derivatives), and 31 (phenylpropanamide analogue). Notably, the maximal (100\%) protection was observed for 2-F (4), 3- $-\mathrm{CF}_{3}(29)$, and 3-OCF 3 (30) congeners. During the next step of pharmacological characterization, all MES-active substances were tested in the mouse $6 \mathrm{~Hz}(32 \mathrm{~mA})$, an animal model of human focal seizures [21] (for details, see Tables S1-S3, Supplementary Materials). The data obtained revealed that 12 molecules $(\mathbf{3}, \mathbf{6}, \mathbf{1 4}, \mathbf{1 9}, \mathbf{2 2}, \mathbf{2 4}, \mathbf{2 5}, \mathbf{2 7 - 3 1})$ protected at least $50 \%$ of mice in this seizure test. The full $(100 \%)$ activity was observed only for $3-\mathrm{OCF}_{3}$ benzylamide derivative 24 , whereas $75 \%$ efficacy was shown for 3, 25, and 27-30. According to the screening results, 11 compounds may be considered as broad-spectrum anticonvulsants that are effective in both MES and $6 \mathrm{~Hz}(32 \mathrm{~mA})$ seizure models, i.e., 3, 6, 14, 19, 22, 24, 25, 27-31. In general, phenylethylamide derivatives $25(\mathrm{H}), 28(4-\mathrm{Cl})$, $29\left(3-\mathrm{CF}_{3}\right)$, and $30\left(3-\mathrm{OCF}_{3}\right)$, and benzylamide derivative $24\left(3-\mathrm{OCF}_{3}\right)$ displayed the most beneficial anticonvulsant properties (i.e., the highest percentage of protection in each seizure model). A narrower spectrum of protection was observed for anilinamides, which were effective predominantly in the MES test (excluding $\mathbf{3}$ and $\mathbf{6}$ ). In parallel to the anticonvulsant screening, all the aforementioned active compounds were studied in the rotarod test to assess their influence on motor coordination of mice. In this assay, none of substances produced acute neurological toxicity at dose of $100 \mathrm{mg} / \mathrm{kg}$ (in some cases, only minimal effects were seen). These results suggest a distinct separation between anticonvulsant effective and toxic doses (i.e., inducing motor deficits), which was confirmed in the in vivo quantitative investigations (for details, see Table 1). According to the aforementioned initial screening data, it may be concluded that the most potent and broad anticonvulsant activity seemed to be provided by the phenylethylamide derivatives. Taking into consideration the optimal substitution mode of the aromatic ring, it can also be concluded that (1) the unsubstituted phenyl rings are preferential for activity in each series, (2) the small substituents such as chlorine or fluorine atoms are preferential in the case of anilinamide derivatives, and (3) chlorine atoms and large trifluoromethyl and trifluoromethoxy groups seem to be more beneficial for activity among benzylamides and phenylethylamides.

In the next step of in vivo characterization, we determined the median effective doses $\left(\mathrm{ED}_{50}\right)$ for all anticonvulsants protecting 50\% or more mice in each seizure model (MES or/and $6 \mathrm{~Hz}(32 \mathrm{~mA})$ ), as well as the median toxic doses $\left(\mathrm{TD}_{50}\right)$ in the rotarod test at the $0.5 \mathrm{~h}$ time point. Both the aforementioned parameters enabled calculation of the protective indexes (PIs), which are a measure of potential therapeutic window of the drug candidate. In parallel, we performed a series of comparative studies using reference compounds, e.g., lacosamide (LCS), lamotrigine (LTG), and valproic acid (VPA), which are active in the MES and $6 \mathrm{~Hz}(32 \mathrm{~mA})$ seizure tests. The obtained results are summarized in Table 1.

As expected on the basis of screening data, phenylethylamides 27, 29, and 30 displayed the most potent activity in the MES and/or $6 \mathrm{~Hz}(32 \mathrm{~mA})$ seizure tests. Satisfactory protection in the MES test (50\%) was shown for a benzylamide derivative $\mathbf{2 1}$ (this compound was unfortunately not effective in the $6 \mathrm{~Hz}$ test). In general, more potent activity was observed in the $6 \mathrm{~Hz}(32 \mathrm{~mA})$ seizure model, and the lowest $\mathrm{ED}_{50}$ values were obtained with 6, 14, 22, 24, 27, 29, and 30. It should be emphasized that all anilinamides $(3,4,6,8,9)$ and benzylamides $(14,19,21,22,24)$ did not impair motor coordination of mice at doses as high as $300 \mathrm{mg} / \mathrm{kg}$. Phenylethylamides 25, 28-30 displayed moderate acute neurological toxicity (at doses around or below $200 \mathrm{mg} / \mathrm{kg}$ ). Among the whole series of hybrid derivatives, the most potent protection in both seizure models and moderate but acceptable acute neurological toxicity were obtained with 30, which was identified as a lead compound. The comparison of data obtained with the test compounds and reference AEDs (VPA in particular) indicated a more potent protection, as well 
as a predominantly more beneficial safety margin (expressed as PIs), for the majority of the hybrid derivatives. It should be emphasized that VPA is still recognized as the most frequently prescribed and the most effective first-line AED in different types of epilepsies [22]. However, potent activity in both seizure models and beneficial PI values were observed for LCS and LTG, which act as sodium channel blockers.

Table 1. The quantitative pharmacological parameters: median effective dose $\left(\mathrm{ED}_{50}\right)$, median toxic dose $\left(\mathrm{TD}_{50}\right)$, and protective indexes (PIs) in mice intraperitoneally (i.p.) injected.

\begin{tabular}{|c|c|c|c|c|c|}
\hline Compound & $\operatorname{TPE}(\mathrm{h})^{a}$ & $\begin{array}{l}\mathrm{ED}_{50} \mathrm{MES} \\
(\mathrm{mg} / \mathrm{kg})^{b}\end{array}$ & $\begin{array}{c}\mathrm{ED}_{50} 6 \mathrm{~Hz}(32 \mathrm{~mA}) \\
(\mathrm{mg} / \mathrm{kg})^{c}\end{array}$ & $\begin{array}{c}\mathrm{TD}_{50}(\text { rotarod }) \\
(\mathrm{mg} / \mathrm{kg})^{d}\end{array}$ & $\mathrm{PI}\left(\mathrm{TD}_{50} / \mathrm{ED}_{50}\right)^{e}$ \\
\hline 3 & 0.5 & $>130$ & 92.5 (72.3-118.3) & $>300$ & $>3.2(6 \mathrm{~Hz})$ \\
\hline 4 & 0.5 & $73.2(58.3-92.8)$ & - & $>300$ & $>4.1$ (MES) \\
\hline 6 & 0.5 & 117.7 (92.6-149.6) & $57.6(33.9-97.9)$ & $>300$ & $\begin{array}{l}>2.5(\mathrm{MES}) \\
>5.2(6 \mathrm{~Hz})\end{array}$ \\
\hline 8 & 0.5 & $73.5(59.3-90.4)$ & - & $>300$ & $>4.1$ (MES) \\
\hline 9 & 0.5 & $105.8(100.3-111.6)$ & - & $>300$ & $>2.8$ (MES) \\
\hline 14 & 0.5 & $>130$ & $62.9(45.7-86.7)$ & $>300$ & $>4.7(6 \mathrm{~Hz})$ \\
\hline 19 & 0.5 & 90.7 (82.6-99.5) & 89.9 (74.4-108.5) & $>300$ & $\begin{array}{l}>3.3(\mathrm{MES}) \\
>3.3(6 \mathrm{~Hz})\end{array}$ \\
\hline 21 & 0.5 & $49.6(44.3-55.7)$ & - & $>300$ & $>6.0(6 \mathrm{~Hz})$ \\
\hline 22 & 0.5 & $>130$ & $57.6(33.9-97.9)$ & $>300$ & $>5.2(6 \mathrm{~Hz})$ \\
\hline 24 & 0.5 & $>130$ & $43.8(33.9-53.8)$ & $>300$ & $>6.8(6 \mathrm{~Hz})$ \\
\hline 25 & 0.5 & $87.9(82.0-94.3)$ & $88.9(83.3-94.9)$ & $\begin{array}{c}210.5 \\
(195.0-227.1)\end{array}$ & $\begin{array}{l}2.4(\mathrm{MES}) \\
2.4(6 \mathrm{~Hz})\end{array}$ \\
\hline 27 & 0.5 & - & $36.3(24.9-53.1)$ & $>300$ & $8.3(6 \mathrm{~Hz})$ \\
\hline 28 & 0.5 & $117.4(108.4-127.3)$ & $88.1(81.8-95.0)$ & $\begin{array}{c}272.5 \\
(253.2-293.3)\end{array}$ & $\begin{array}{l}2.3(\mathrm{MES}) \\
2.9(6 \mathrm{~Hz})\end{array}$ \\
\hline 29 & 0.5 & $55.4(41.5-65.4)$ & $49.3(38.0-62.1)$ & $\begin{array}{c}178.8 \\
(164.1-188.5)\end{array}$ & $\begin{array}{l}3.2(\mathrm{MES}) \\
3.6(6 \mathrm{~Hz})\end{array}$ \\
\hline 30 & 0.5 & $45.6(35.8-58.2)$ & $39.5(28.3-55.2)$ & $\begin{array}{c}162.4 \\
(144.0-183.1)\end{array}$ & $\begin{array}{l}3.5(\mathrm{MES}) \\
4.1(6 \mathrm{~Hz})\end{array}$ \\
\hline 31 & 0.5 & - & $103.8(86.1-125.2)$ & $>300$ & $2.9(6 \mathrm{~Hz})$ \\
\hline $\operatorname{LCS}^{f}$ & 0.5 & $9.2(8.5-10.0)$ & $5.3(3.5-7.8)$ & $46.2(44.5-48.0)$ & $\begin{array}{l}5.0(\mathrm{MES}) \\
8.8(6 \mathrm{~Hz})\end{array}$ \\
\hline LTG $^{f}$ & 1.0 & $3.1(1.9-4.7)$ & $6.4(4.1-9.9)$ & $48.3(37.4-62.6)$ & $\begin{array}{l}15.6(\mathrm{MES}) \\
7.5(6 \mathrm{~Hz})\end{array}$ \\
\hline VPA $^{f}$ & 0.5 & $252.7(220.1-290.2)$ & $130.6(117.6-145.2)$ & $\begin{array}{c}430.7 \\
(407.9-454.9)\end{array}$ & $\begin{array}{l}1.7(\mathrm{MES}) \\
3.3(6 \mathrm{~Hz})\end{array}$ \\
\hline
\end{tabular}

Values in parentheses are $95 \%$ confidence intervals determined by probit analysis [23]. ${ }^{a}$ Time to peak effect; ${ }^{b} \mathrm{ED}_{50}$ (MES, maximal electroshock seizure test); ${ }^{c} \mathrm{ED}_{50}(6 \mathrm{~Hz}$ psychomotor seizure test, $32 \mathrm{~mA}) ;{ }^{d} \mathrm{TD}_{50}$ (acute neurological toxicity determined in the rotarod test); ${ }^{e}$ protective index $\left(\mathrm{TD}_{50} / \mathrm{ED}_{50}\right) ;{ }^{f}$ reference antiepileptic drugs (AEDs): lacosamide (LCS), lamotrigine (LTG), and valproic acid (VPA) tested in the same conditions. TPEs for model AEDs taken from own experiments. A dash indicates not tested.

In summary, the proposed structural modification relying on the introduction of the additional phenyl moiety in the acetamide linker did not increase activity in the MES test compared to aliphatic analogues represented by maternal compounds DK-1 and AS-1 (see Figure 1), which was the main hypothesis behind the current series of compounds. It should be stressed, however, that several substances (e.g., 21, 24, 27, 29, and 30) revealed beneficial anticonvulsant activity, with an acceptable safety profile; thus, they may be subjects for further structural optimization. 


\subsection{Antinociceptive Activity}

AEDs are also commonly used in the treatment of neuropathic pain and other central pain conditions. Therefore, with an aim of further pharmacological characterization of compounds described herein, we decided to study their antinociceptive properties in the in vivo assays. These studies were performed for two representative molecules with different anticonvulsant profiles, namely, compound 4, which showed protection exclusively in the MES test, and 30, which was active in both MES and $6 \mathrm{~Hz}$ $(32 \mathrm{~mA})$ seizure models. At first, both aforementioned compounds were tested in the formalin-induced tonic pain model, which is recognized as a valuable screening tool [24]. In this test, the injection of formalin into the plantar surface of the mouse paw produces specific behaviors like paw lifting, flinching, and licking. Furthermore, the nociceptive response is biphasic where, in phase I ( $0-5 \mathrm{~min})$, pain results from the direct activation of primary nociceptive afferents, and, in phase II (10-30 min), pain results mainly from the central sensitization in the dorsal horn of the spinal cord [25]. Moreover, it has been reported that formalin induces pathological changes that resemble those observed in nerve injury and neuropathic pain [24]. Thus, this test has been successfully used to assess the analgesic efficacy of a variety of compounds such as opioids, nonsteroidal anti-inflammatory drugs (NSAIDs), corticosteroids, and $N$-methyl-D-aspartate (NMDA) receptor antagonists, as well as AEDs such as carbamazepine, topiramate, or gabapentin [26,27].

As mentioned above, we investigated the analgesic properties of two of the most promising and interesting compounds: 4 and 30. As shown in Figure 2, the i.p. administration of compound 4 prior to the subcutaneous injection of formalin attenuated the nociceptive response in mice in both phases of the test; however, in the first phase, the activity was statistically significant only at the highest dose of $120 \mathrm{mg} / \mathrm{kg}$. It was slightly more efficient in the second phase of the model with an $\mathrm{ED}_{50}$ value equal to $98.9 \mathrm{mg} / \mathrm{kg}$. In contrast, compound $\mathbf{3 0}$ was much more effective (almost four times more potent) in both phases (phase I: $\mathrm{ED}_{50}=21.5 \mathrm{mg} / \mathrm{kg}$ and phase II: $\mathrm{ED}_{50}=24.8 \mathrm{mg} / \mathrm{kg}$ ). Particularly interesting is the activity of the compound in the first phase, since it suggests its efficacy with regard to the pain associated with acute and direct damage/disfunction of the nerve endings. These results showed favorable analgesic properties, especially for compound 30, which were subsequently confirmed in other models of pain such as capsaicin-induced neurogenic pain and oxaliplatin (OXPT)-induced neuropathic pain in mice.
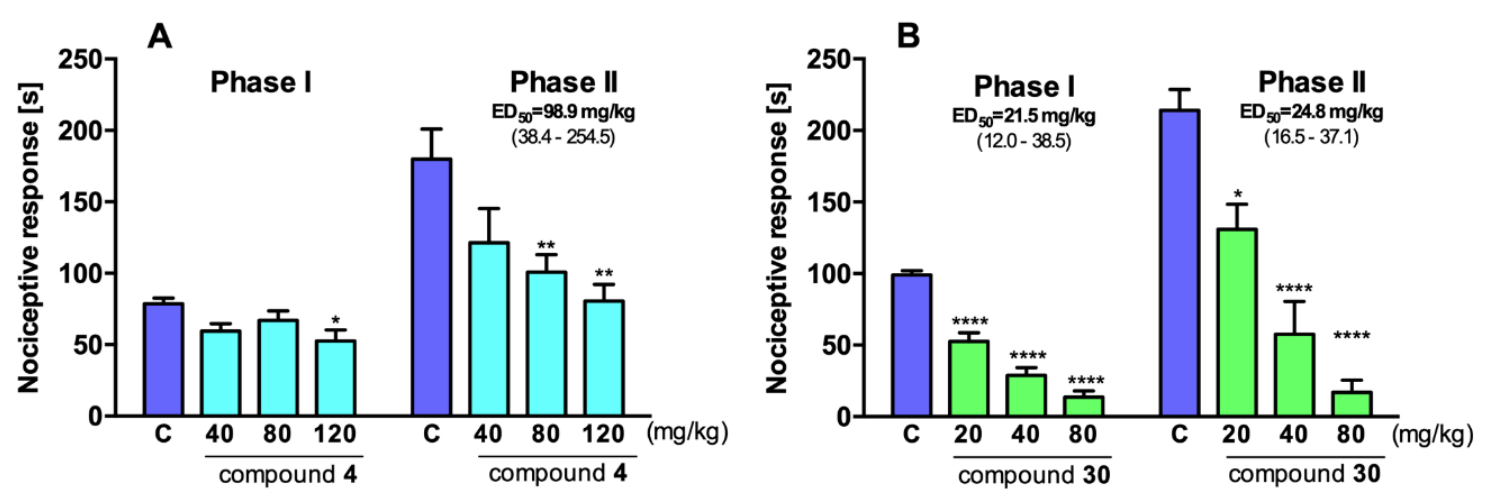

Figure 2. Antinociceptive activity of compounds 4 (A) and 30 (B) in the formalin test. Results are shown as time of licking in phase I ( $0-5$ min after intraplantar injection of formalin) and in phase II (15-30 min after formalin injection). Each value represents the mean \pm standard error of the mean (SEM) for 8-10 animals. Statistical analysis: one-way ANOVA followed by post hoc Dunnett's test. Statistical significance compared to vehicle-treated animals (Tween): ${ }^{*} p<0.05,{ }^{* *} p<0.01, * * * *<0.0001$. C-control group.

We used the capsaicin-induced model of pain to test the potential of the compounds to inhibit the neurogenic (acute) response to noxious stimuli, which was suggested by their activity in the first phase of the formalin test. Capsaicin activates $C$ polymodal fibers and enhances their firing, which contributes 
to subsequent hyperalgesia. The molecular mechanism of action of capsaicin is the activation of the nonselective cation channel, transient receptor potential vanilloid-1 (TRPV1), which is localized on nociceptive free nerve endings. That induces the release of proinflammatory neuropeptides such as calcitonin gene-related peptide (CGRP), vasoactive intestinal peptide (VIP), and substance P (SP). The phenomenon of the induction of tissue inflammation by the peripheral nervous system is called neurogenic inflammation, and it is involved in the development of inflammatory and neuropathic pain. AEDs such as gabapentin, topiramate, or lamotrigine decrease capsaicin-induced nocifensive behavior [25]. We observed a similar effect especially in the case of compound 30, which significantly attenuated the nociceptive response induced by capsaicin in a dose-dependent manner (Figure 3B). Its $\mathrm{ED}_{50}$ value was found to be $35.3 \mathrm{mg} / \mathrm{kg}$. Compound 4 was less active and was able to significantly attenuate nociceptive response in capsaicin-induced pain by $37.9 \%$, but only at the highest applied dose of $120 \mathrm{mg} / \mathrm{kg}$ (Figure 3A). The obtained results show that the test compound 30 has the potential for inhibiting acute, neurogenic pain, probably by stabilizing the firing polymodal fibers and/or central mechanisms of analgesia.
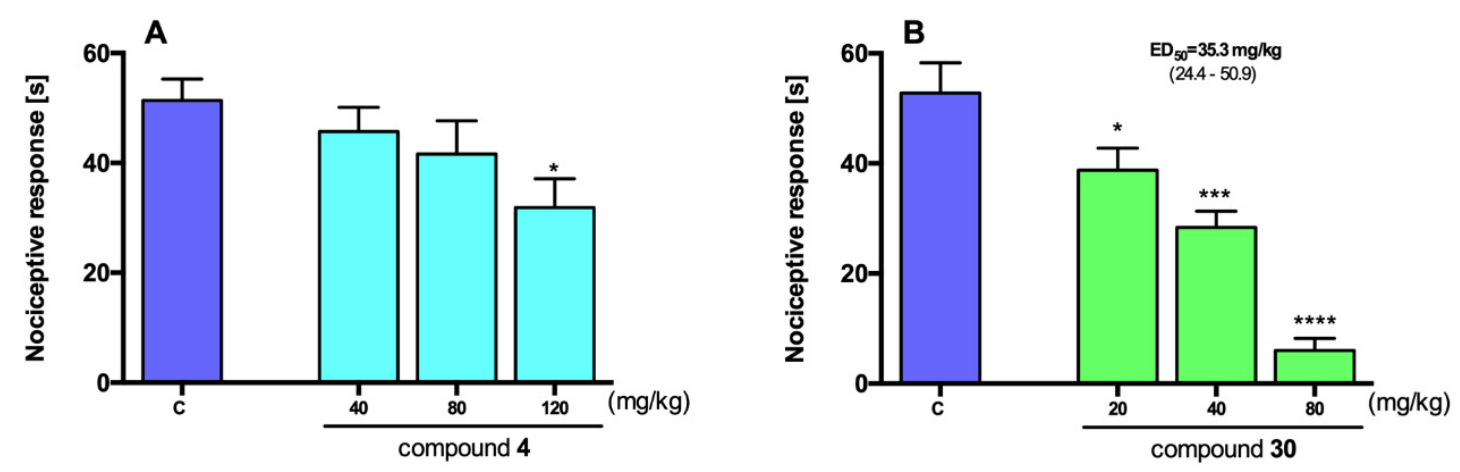

Figure 3. Antinociceptive activity of compounds 4 (A) and 30 (B) in the capsaicin test. Results are shown as time of licking in the period of $5 \mathrm{~min}$ after intraplantar injection of capsaicin. Each value represents the mean \pm SEM for 8-10 animals. Statistical analysis: one-way ANOVA followed by post hoc Dunnett's test. Statistical significance compared to vehicle-treated animals (Tween): ${ }^{*} p<0.05$, *** $p<0.00,{ }^{* * * *} p<0.0001$. C-control group.

In order to investigate the analgesic activity of the most promising compound $\mathbf{3 0}$ in a neuropathic pain model, we tested it in oxaliplatin (OXPT)-induced peripheral neuropathy, in which mechanical and cold allodynia result from impaired function of ion channels, among others [28]. The early phase of neuropathic pain appears hours after OXPT administration, while the late phase develops days after OXPT. Thus, we tested compound $303 \mathrm{~h}$ and 7 days after the injection of OXPT. We investigated the influence of compound $\mathbf{3 0}$ on tactile allodynia using the von Frey method. Three hours after the administration of OXPT we observed a significant decrease in the mean value of force that caused paw withdrawal reaction $(1.89 \pm 0.04 \mathrm{~g})(64.2 \%$ of the baseline) compared to nontreated animals $(2.94 \pm 0.06 \mathrm{~g})$ (the baseline). Seven days after OXPT administration, the pain threshold was $2.00 \pm 0.03$ ( $68.0 \%$ of the baseline). The observed tactile allodynia was attenuated by compound 30 , which elevated pain sensitivity threshold in the early phase in a dose-dependent manner (Figure 4) $(2.26 \pm 0.08 \mathrm{~g}$, $2.49 \pm 0.05 \mathrm{~g}$, and $2.97 \pm 0.05 \mathrm{~g}$ at the dose of $20 \mathrm{mg} / \mathrm{kg}, 40 \mathrm{mg} / \mathrm{kg}$, and $80 \mathrm{mg} / \mathrm{kg}$, respectively, which correspond to $76.8 \%, 84.7 \%$, and $101.0 \%$ of the baseline value). In the late phase, the values of pain threshold were as follows $2.18 \pm 0.06 \mathrm{~g}, 2.60 \pm 0.08 \mathrm{~g}$, and $2.91 \pm 0.05 \mathrm{~g}$, which correspond to $74.1 \%, 88.4 \%$, and $98.9 \%$ of the baseline value. These results indicate that compound 30 has the potential for relieving neuropathic pain. 


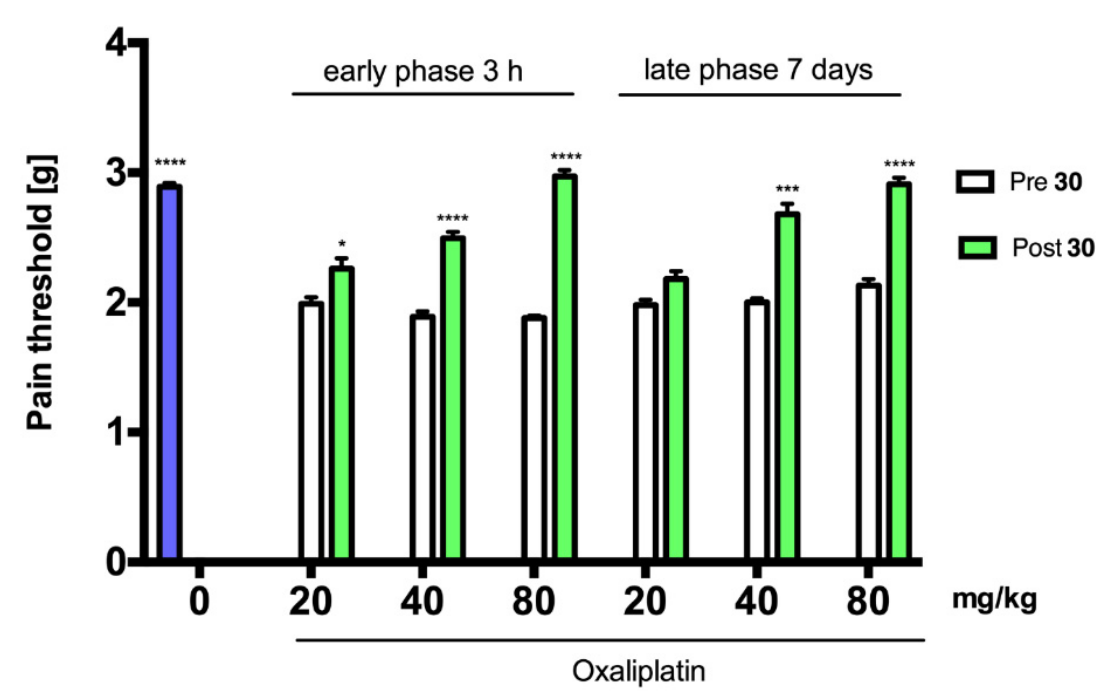

Figure 4. Antiallodynic effects of compound 30 administered at the doses of $20 \mathrm{mg} / \mathrm{kg}, 40 \mathrm{mg} / \mathrm{kg}$, and $80 \mathrm{mg} / \mathrm{kg}$ in the tactile allodynia evaluated in the von Frey test in the oxaliplatin (OXPT)-induced model of peripheral neuropathy. Results compared to vehicle-treated group (pre 30). Statistical analysis: repeated measures analysis of variance (ANOVA), followed by Dunnett's post hoc comparison: ${ }^{*} p<0.05$, $* * * p<0.001, * * * * 0.0001$.

\subsection{In Vitro Radioligand Binding Studies and Functional Assays}

The previous studies in series of 2-(2,5-dioxopyrrolidin-1-yl)propanamides, represented by compounds AS-1 and DK-1 (see Figure 1), showed that these molecules interact with voltage-gated sodium channels and $\mathrm{Cav}_{1.2}$ (L-type) calcium channels at very high concentrations of $100 \mu \mathrm{M}$ or $500 \mu \mathrm{M}$ [12]. Taking into consideration the structural similarities of molecules described in the current manuscript with their chemical prototypes AS-1 and DK-1, the binding studies toward aforementioned molecular targets were performed commercially for several active substances from each subseries $(3,4,21,24,25,27,29$, and 30). Furthermore, we also tested two other and well-known targets for AEDs, namely, the Cav2.2 ( $\mathrm{N}$-type) calcium channel and gamma-aminobutyric acid (GABA)-A receptor. With the aim of excluding potentially dangerous proarrhythmic properties for each compound, their interaction with the potassium (hERG) channel was also tested. Notably, the potassium (hERG) channel is recognized as one of the most important off-targets, and the potential effects on this ion channel should be eliminated in early stages of the new drug development. The details are shown in Table 2.

The results of the binding studies showed that only four compounds 24, 27, 29, and 30 revealed moderate binding to voltage-gated calcium channels $\operatorname{Cav}_{1.2}$ at a concentration of $10 \mu \mathrm{M}$. Importantly, these substances were also identified as the most effective anticonvulsants with potent protection especially in the $6 \mathrm{~Hz}(32 \mathrm{~mA})$ seizure model. Thus, the interaction with Cav ${ }_{1.2}$ channels seems to be at least partially responsible for activity in the aforementioned model of focal seizures. These observations are consistent with results obtained in our previous studies that clearly indicate on $\mathrm{Cav}_{1.2}$ channel antagonism as an important mechanism underlying anticonvulsant properties [13-15]. Notably, it is well known that $\mathrm{Cav}_{1.2}$ channels are widely localized in the CNS neurons, predominantly on post-synaptic parts; consequently, they regulate neuronal firing [29]. It should be emphasized that the most current neurobiological studies implicate $\mathrm{Cav}_{1.2}$ channels in the pathogenesis of chronic and neuropathic pain [30]. Thus, antagonists of these ion channels may be considered as promising candidates for new antinociceptive drugs [31]. The functional assays applying the cell-based flux studies performed for compounds $\mathbf{2 4}, \mathbf{2 7}, \mathbf{2 9}$, and 30 showed their moderate antagonist properties (Table 3). 
Table 2. In vitro binding assays for several compounds at concentration of $10 \mu \mathrm{M}$ or $100 \mu \mathrm{M}$.

\begin{tabular}{|c|c|c|c|c|c|}
\hline \multirow[b]{2}{*}{ Assay } & \multicolumn{5}{|c|}{$\%$ Inhibition of Control Specific Binding ${ }^{a}$} \\
\hline & $\begin{array}{c}\mathrm{Na}^{+} \text {Channel (Site 2) } \\
\text { (Antagonist } \\
\text { Radioligand) }{ }^{*} \#\end{array}$ & $\begin{array}{l}\text { Cav1.2 Channel } \\
\text { (Antagonist } \\
\text { Radioligand)* }\end{array}$ & $\begin{array}{l}\text { Cav }_{2.2} \text { Channel } \\
\text { (Antagonist } \\
\text { Radioligand) * }\end{array}$ & $\begin{array}{c}\text { GABA-A Receptor } \\
\left(\alpha_{1}, \beta_{2}, \gamma_{2}\right) \\
\text { (Agonist Radioligand) * }\end{array}$ & $\begin{array}{c}\text { Potassium } \\
\text { Channel } \\
(\text { hERG) }\end{array}$ \\
\hline $\begin{array}{c}\text { Concentration } \\
(\mu \mathrm{M})\end{array}$ & 10 & 10 & 10 & 10 & 100 \\
\hline \multicolumn{6}{|l|}{ Compound } \\
\hline 4 & 23.5 & 5.0 & 1.1 & 2.8 & 2.3 \\
\hline 21 & 18.8 & 26.6 & 0.2 & 1.2 & 6.3 \\
\hline 24 & 22.3 & 36.5 & 5.5 & -0.8 & 4.4 \\
\hline 25 & 14.8 & 19.0 & 2.5 & 3.6 & 4.8 \\
\hline 27 & 20.1 & 38.3 & 3.8 & 0.7 & 2.7 \\
\hline 29 & 18.3 & 44.2 & -0.6 & 2.1 & 3.4 \\
\hline
\end{tabular}

The data for the most potent compounds have been bolded for better visualization. ${ }^{a}$ Results showing activity higher than $50 \%$ are considered to represent a significant effect of the test compounds; results showing an inhibition between $25 \%$ and $50 \%$ (bolded values) are indicative of a moderate effect; results showing an inhibition lower than $25 \%$ are not considered significant. \# Central nervous system (CNS) tetrodotoxin (TTX)-sensitive sodium channels that include $\mathrm{Na}_{\mathrm{v}} 1.1, \mathrm{Na}_{\mathrm{v}} 1.2, \mathrm{Na}_{\mathrm{v}} 1.3$, and $\mathrm{Na}_{\mathrm{v}} 1.6$ subtypes. Binding studies were performed commercially in Eurofins Cerep SA (Celle l'Evescault, France). Source: * rat cerebral cortex; ${ }^{* *}$ human recombinant (HEK-293 cells).

Table 3. In vitro functional assays for several compounds at concentration of $10 \mu \mathrm{M}$.

\begin{tabular}{cc}
\hline Molecular Target & $\begin{array}{c}\text { \% Inhibition of Control Agonist Response }{ }^{a} \\
\text { Assay }\end{array}$ \\
\hline Compound & $\begin{array}{c}\text { Calcium Ion Channel Cell-Based Antagonist Calcium Flux } \\
\text { Assay (Human Recombinant (HEK-293 Cells)) }\end{array}$ \\
\hline 21 & 27.0 \\
24 & 38.8 \\
27 & 40.0 \\
29 & 45.0 \\
30 & 49.0 \\
\hline
\end{tabular}

The data for the most potent compounds have been bolded for better visualization. ${ }^{a}$ Results showing an inhibition higher than $50 \%$ are considered to represent a significant effect of the test compounds; results showing an inhibition between $25 \%$ and $50 \%$ (bolded values) are indicative of a moderate effect; results showing an inhibition lower than $25 \%$ are not considered significant. Functional studies were performed commercially in Eurofins Panlabs Discovery Services Taiwan, Ltd. (New Taipei City, Taiwan).

Interestingly, none of the tested compounds interacted with voltage-gated sodium channels, $\mathrm{Cav}_{2.2}$ calcium channels, GABA-A receptors, and especially the potassium (hERG) channel at concentrations as high as $100 \mu \mathrm{M}$. The latter result is particularly important since it minimizes the risk of potential proarrhythmic activity of these compounds. Summing up, on the basis of the binding and functional studies, it may be concluded that $\operatorname{Cav}_{1.2}$ channel antagonism is probably involved in the mechanism of action for the compounds reported herein. Nevertheless, it should be stressed that the identification of additional and currently undefined molecular targets responsible for the biological properties is highly possible during further in vitro characterization.

\subsection{In Vitro ADME-Tox Assays}

Long-term use of AEDs may often lead to numerous adverse effects both acute (affecting the CNS and the gastrointestinal tract) and chronic (including neuropsychiatric disorders or gastrointestinal tract, endocrine, hematologic, liver, metabolic, dermatologic, and systemic symptoms) [32], as well as drug-drug interactions (DDIs), especially with the metabolic origin mediated by different isoforms of cytochrome P450 (CYP). Until now, 10 CYP isoforms have been identified in a typical human liver, and six of them (CYP1A2, CYP2C8, CYP2C9, CYP2C19, CYP2D6, and CYP3A4) appear to be 
engaged in biotransformation of most drugs. Notably, among these isoforms, CYP3A4, CYP2D6, and CYP2C9 are responsible for the metabolism of more than $50 \%$ of marketed drugs and the associated DDIs. The induction or inhibition of these P450 isotypes may influence the metabolic clearance and blood concentration of co-administered drugs, resulting in lower therapeutic efficacy or toxic drug effects, respectively. The problems related with the DDIs are especially visible for the first generation of AEDs which may interact with different CYP isoforms. The clearest examples of these adverse effects are phenytoin, phenobarbital, and carbamazepine which are known as CYP3A4, CYP2C9, CYP1A2, and CYP2B6 inductors, and valproic acid, recognized as a CYP2C9 inhibitor. Notably, the DDIs are described also for the newest AEDs, e.g., cannabidiol (CBD) and clobazam. Clobazam, during the biotransformation, is N-demethylated by CYP3A4 and, to a lesser extent, by CYP2C19 and CYP2B. The main metabolite, $N$-desmethylclobazam (or norclobazam), is hydroxylated next by CYP2C19. The DDI between CBD and clobazam leading to a significant increase in the level of $N$-desmethylclobazam results from inhibition of CYP2C19 activity by CBD [33]. It should also be stressed herein that some AEDs (including the newest preparations) form toxic metabolites during biotransformation, e.g., the reactive metabolite of felbamate causing aplastic anemia [34] or the 10,11-epoxide of carbamazepine, which facilitates its and the parent drug's metabolism (autoinduction) [35]. Consequently, the evaluation of CYPs induction/inhibition or hepatotoxic potential of new biologically active compounds is crucial at an earlier stage of drug development.

Considering the aforementioned facts, drug-like properties of the most promising compounds from each subseries $(\mathbf{4}, \mathbf{2 4}, \mathbf{3 0})$ were estimated next within this study. Standard in vitro methods were used for ADME-Tox parameter evaluation. All tests were performed acording to descrived previously protocols $[14,15,36]$.

\subsubsection{Parallel Artificial Membrane Permeability Assay (PAMPA)}

Passive diffusion was tested in the parallel artificial membrane permeability assay (PAMPA) and expressed as the permeability coefficient (Pe). A highly permeable compound, caffeine (CFN), and a poorly permeable compound, norfloxacin (NFX), were used as the references. All compounds selected for this assay $(4,24$ and 30) showed very high ability to passively diffuse through the biological membranes with Pe values close to or even higher (compound 30) than CFN (Table 4).

Table 4. The results obtained in parallel artificial membrane permeability assay (PAMPA), expressed as the permeability coefficient $(P e)$.

\begin{tabular}{ll}
\hline \multicolumn{1}{c}{ Compound } & $\boldsymbol{P e}\left(\mathbf{1 0}^{-\mathbf{6}} \mathbf{c m} / \mathbf{s}\right) \pm$ SD $^{\mathbf{a}}$ \\
\hline CFN $^{\mathrm{b}}$ & $12.22 \pm 0.9$ \\
NFX $^{\mathrm{c}}$ & $0.056 \pm 0.0$ \\
$\mathbf{4}$ & $11.25 \pm 0.7$ \\
$\mathbf{2 4}$ & $10.87 \pm 0.5$ \\
$\mathbf{3 0}$ & $13.20 \pm 1.5$ \\
a $^{\text {Tested in triplicate; }}{ }^{\mathrm{b}}$ caffeine $(\mathrm{CFN}){ }^{\mathrm{c}}{ }^{\text {norfloxacin }(\mathrm{NFX})}$.
\end{tabular}

\subsubsection{Metabolic Stability}

Human liver microsomes (HLMs) were used for metabolic stability determination. Moreover, the most probable phase I reactions and structures of metabolites were proposed according to ion fragment analyses with the in silico support of MetaSite 6.0.1 software. In general, pyrrolidine-2,5-dione derivatives displayed satisfied stability as their conversion into metabolites was lower than $30 \%$ during 120 min incubation with HLMs. These results correlate with our previous studies, where high metabolic stability within this chemical group was also found $[9,12,14,15,37]$. Compound 4 showed the highest susceptibility for enzymatic biotransformations (71.4\% of parent compound remained in the reaction mixture; see Figure S1, Supplementary Materials), resulting in double-hydroxylations 
(M1), pyrrolidine-2,5-dione ring hydrolysis (M2), or monohydroxylation (M3) as the most probable metabolic pathways (Figures S2 and S7, Supplementary Materials). On the other hand, an excellent metabolic stability of compound 24 was observed. Less than $4 \%$ of this derivative was converted into double-hydroxylated metabolite M1 (Figures S3, S4, and S7, Supplementary Materials). Finally, two monohydroxylated metabolites (M1, M2) were found in the reaction mixture with HLMs and 30, and around $17 \%$ of this compound was metabolized (Figures S5-S7, Supplementary Materials).

\subsubsection{Influence on Function of Cytochrome P450 Isoforms-CYP3A4, CYP2D6, and CYP2C9}

The luminescent CYP3A4, 2D6, and 2C9 P450-Glo assays were used for the prediction of DDIs risk. In case of CYP3A4, all tested derivatives statistically significantly inhibited its activity at $10 \mu \mathrm{M}$. The highest inhibition was observed for derivatives with trifluoromethoxy substituent 24 and $\mathbf{3 0}$. These compounds still slightly inhibited CYP3A4 activity $(p<0.05)$ even at low concentration $(1 \mu \mathrm{M})$. However, this effect was much weaker than that observed for $1 \mu \mathrm{M}$ of the reference CYP3A4 inhibitor ketoconazole (KE) (Figure 5)

Furthermore, slight but statistically significant activation of CYP2D6 was observed for all compounds, whereas quinidine (QD) used here as the reference inhibited this isoform entirely at $1 \mu \mathrm{M}$ (Figure 6).

Surprisingly, the opposite effect on CYP2C9 was observed within this group, whereby compounds 4 and 30 blocked its activity at the highest concentrations of 10 and $25 \mu \mathrm{M}$, whereas the same doses of 24 activated this CYP isoform up to $140 \%$ of control. However, the observed inhibition effect of 4 and 30 was found to be weaker in comparison to the reference inhibitor sulfaphenazole (SE), which almost completely blocked CYP2C9 activity at $1 \mu \mathrm{M}$ (Figure 7).

\subsubsection{Determination of Hepatotoxicity Risk}

The hepatotoxicity assessment was done with use of hepatoma HepG2 cells, which were incubated for $72 \mathrm{~h}$ in the presence of $1-100 \mu \mathrm{M}$ concentrations of 4, 24, and 30. The CellTiter $96^{\circledR}$ aqueous nonradioactive cell proliferation assay (MTS) purchased from Promega (Madison, WI, USA) was used for determination of cell viability. The absorbance was measured using a microplate reader EnSpire (PerkinElmer, Waltham, MA, USA) at $492 \mathrm{~nm}$. The obtained results confirmed the safety of the investigated series. The statistically significant $(p<0.001)$ effect on cells viability was determined for compound 30, but only at the very high concentration of $100 \mu \mathrm{M}$ (Figure 8).

Overall, the results obtained in the in vitro ADME-Tox assays indicate satisfactory drug-like properties of all tested compounds $(\mathbf{4}, \mathbf{2 4}$, and $\mathbf{3 0}$ ). In particular, very high (similar to CFN) passive diffusion in PAMPA, excellent metabolic stability, and low hepatotoxic effects were confimed. In general, DDI assays showed potential interactions of tested derivatives with all CYP isoforms used. However, the observed effects were much weaker than when using the reference inhibitors KE, QD, and SE. 

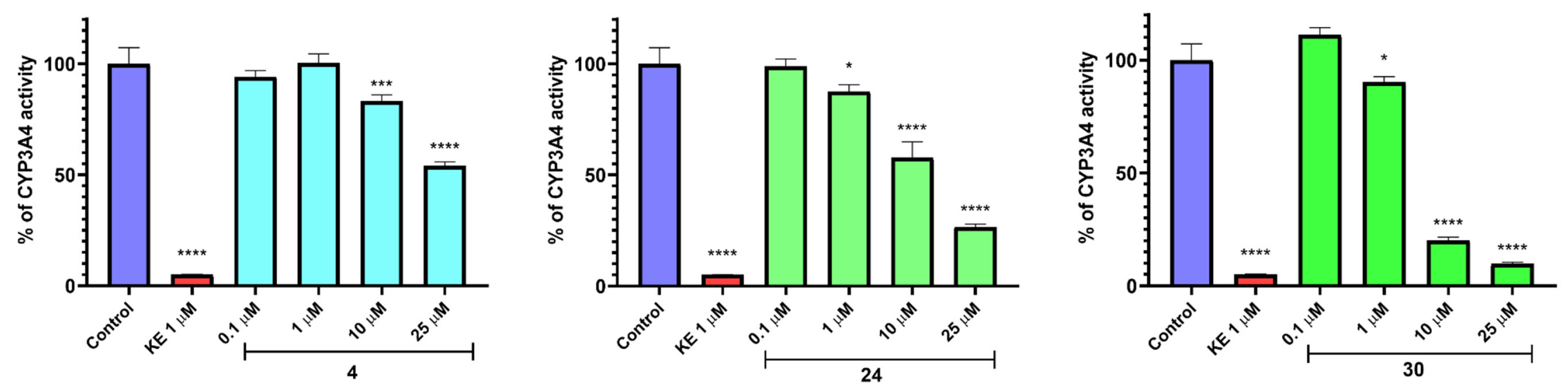

Figure 5. The influence of $4, \mathbf{2 4}, \mathbf{3 0}$, and reference inhibitor ketoconazole (KE) on CYP3A4 activity. Statistical significance $\left(^{*} p<0.05,{ }^{* * *} p<0.001,{ }^{* * * *} p<0.0001\right)$ was analyzed by Graph Pad Prism 8.0.1 software using one-way ANOVA and Bonferroni's multiple comparison post test. The compounds were examined in triplicate.
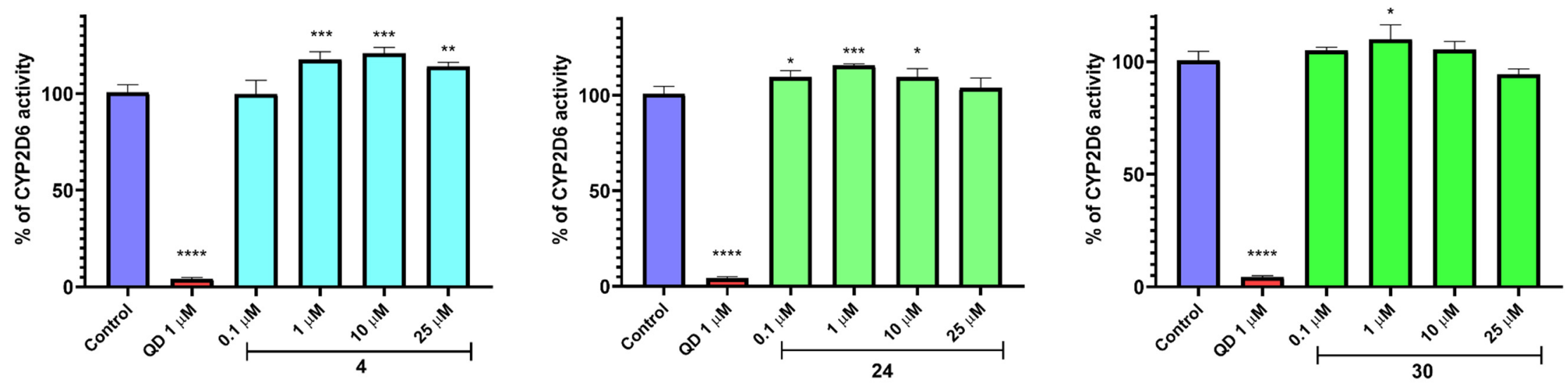

Figure 6. The influence of 4, 24, 30, and reference inhibitor quinidin (QD) on CYP2D6 activity. Statistical significance $\left({ }^{*} p<0.05,{ }^{* *} p<0.01,{ }^{* * *} p<0.001,{ }^{* * * *} p<0.0001\right)$ was analyzed by Graph Pad Prism 8.0.1 software using one-way ANOVA and Bonferroni's multiple comparison post test. The compounds were examined in triplicate. 

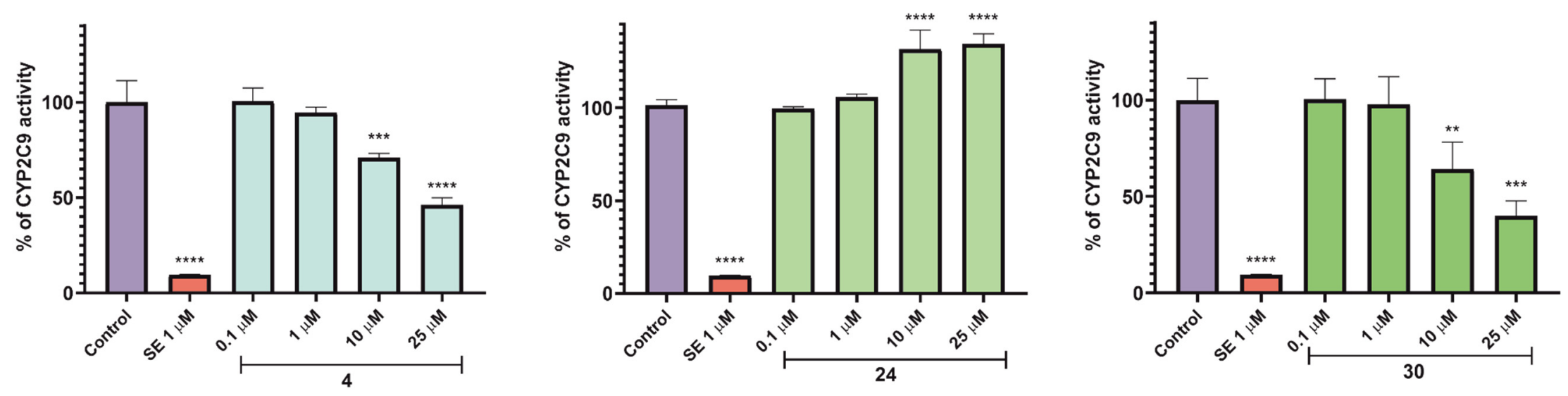

Figure 7. The influence of $4, \mathbf{2 4}, \mathbf{3 0}(10 \mu \mathrm{M})$ and the reference inhibitor sulfaphenazole (SE) on CYP2C9 activity. Statistical significance $\left(^{* * *} p<0.01,{ }^{* * *} p<0.001\right.$, ${ }^{* * * *} p<$ 0.0001) was analyzed by Graph Pad Prism 8.0.1 software using one-way ANOVA and Bonferroni's multiple comparison post test. The compounds were examined in triplicate.
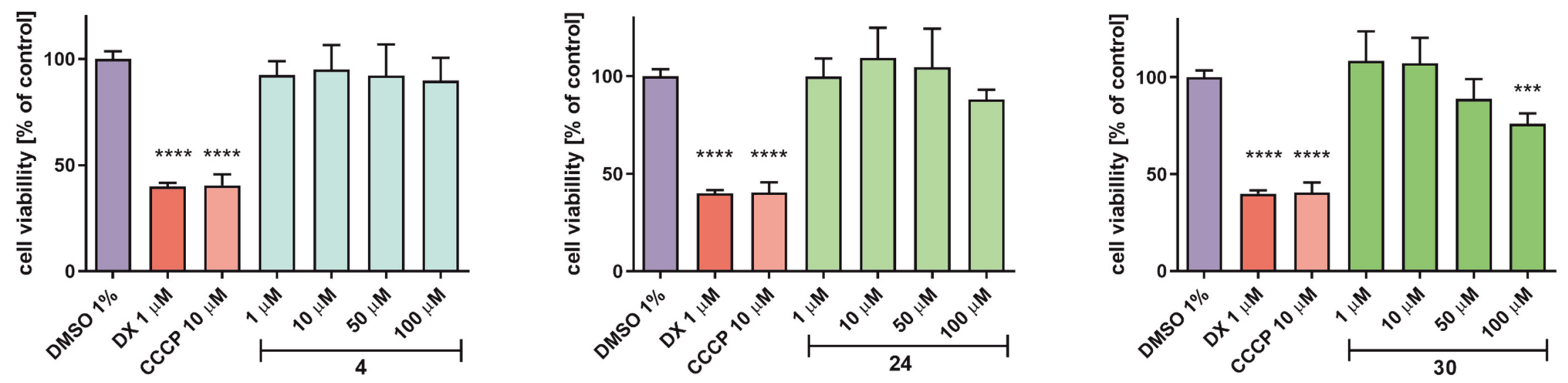

Figure 8. The effect of 4, 24, 30, and cytostatic drug doxorubicin (DX) and the mitochondrial toxin carbonyl cyanide 3-chlorophenyl-hydrazone (CCCP) on hepatoma HepG2 cell lines viability after $72 \mathrm{~h}$ of incubation at $37^{\circ} \mathrm{C}, 5 \% \mathrm{CO}_{2}$. The statistical significance (GraphPad Prism 8.0.1) was evaluated by a one-way ANOVA, followed by Bonferroni's comparison test $\left.{ }^{* * *} p<0.001,{ }^{* * * *} p<0.0001\right)$ compared with negative control dimethyl sulfoxide (DMSO) $1 \%$ in growth medium). 


\section{Materials and Methods}

\subsection{Chemistry}

All chemicals and solvents were purchased from Sigma-Aldrich (St. Louis, MO, USA) and were used without further purification. Melting points (m.p.) were determined in open capillaries on a Büchi 353 melting point apparatus (Büchi Labortechnik, Flawil, Switzerland). Thin-layer chromatography (TLC) and gradient UPLC chromatography were used to assess the purity and homogeneity of the compounds. TLC was carried out on silica gel $60 \mathrm{~F}_{254}$ pre-coated aluminum sheets (Macherey-Nagel, Düren, Germany), using the following developing systems: $\mathrm{S}_{1}-\mathrm{DCM} \mathrm{MeOH}$ (9:0.3; $v / v), \mathrm{S}_{2}-\mathrm{DCM}: \mathrm{MeOH}(9: 0.5 ; v / v), \mathrm{S}_{3}-\mathrm{DCM}: \mathrm{MeOH}(9: 0.7 ; v / v), \mathrm{S}_{4}-\mathrm{DCM}: \mathrm{MeOH}(9: 1 ; v / v)$. Spot detection was carried out using ultraviolet (UV) light $(\lambda=254 \mathrm{~nm}$ ). The UPLC and mass spectra (LC-MS) were obtained on a Waters ACQUITY'TM TQD system (Waters, Milford, CT, USA) with the MS-TQ detector and UV-Vis-DAD e $\lambda$ detector. The ACQUITY UPLC BEH C18, $1.7 \mu \mathrm{m}(2.1 \times 100 \mathrm{~mm})$ column was used with the VanGuard Acquity UPLC BEH C18, $1.7 \mu \mathrm{m}(2.1 \times 5 \mathrm{~mm})$ (Waters, Milford, CT, USA). Standard solutions $(1 \mathrm{mg} / \mathrm{mL})$ of each compound were prepared in an analytical grade $\mathrm{MeCN} /$ water mixture $(1: 1 ; v / v)$. Conditions applied were as follows: eluent $\mathrm{A}$ (water/0.1\% $\mathrm{HCOOH}$ ), eluent $\mathrm{B}(\mathrm{MeCN} / 0.1 \% \mathrm{HCOOH})$, a flow rate of $0.3 \mathrm{~mL} / \mathrm{min}$, a gradient of $5-100 \%$ B over $10 \mathrm{~min}$, and an injection volume of $10 \mu \mathrm{L}$. The UPLC retention times $\left(t_{\mathrm{R}}\right)$ are given in minutes. The purity of target compounds determined by use of chromatographic UPLC method was $\geq 95 \%$. Preparative column chromatography was performed using silica gel 60 (particle size 0.063-0.200; 70-230 Mesh ATM) purchased from Macherey-Nagel (Duren, Germany). Elemental analyses (C, H, and N) for final compounds were carried out by a micro method using the elemental Vario EI III Elemental analyzer (Hanau, Germany). The results of elemental analyses were within $\pm 0.4 \%$ of the theoretical values. ${ }^{1} \mathrm{H}-\mathrm{NMR}$ and ${ }^{13} \mathrm{C}-\mathrm{NMR}$ spectra were obtained in $\mathrm{CDCl}_{3}$ or dimethyl sulfoxide (DMSO)- $\mathrm{D}_{6}$ in a Varian Mercury spectrometer (Varian Inc., Palo Alto, CA, USA), in DMSO-D 6 operating at $300 \mathrm{MHz}\left({ }^{1} \mathrm{H}-\mathrm{NMR}\right)$ and $75 \mathrm{MHz}\left({ }^{13} \mathrm{C}-\mathrm{NMR}\right)$, or in a JEOL-500 spectrometer (JEOL USA, Inc. MA, USA), in $\mathrm{CDCl}_{3}$ operating at $500 \mathrm{MHz}\left({ }^{1} \mathrm{H}-\mathrm{NMR}\right)$ and $126 \mathrm{MHz}\left({ }^{13} \mathrm{C}-\mathrm{NMR}\right)$. Chemical shifts are reported in $\delta$ values (ppm) relative to tetramethylsilane (TMS) $\delta=0\left({ }^{1} \mathrm{H}\right)$, as an internal standard. The $J$ values are expressed in Hertz (Hz). Signal multiplicities are represented by the following abbreviations: s (singlet), br. s (broad singlet), d (doublet), dd (doublet of doublet), dq (doublet of quartets), $\mathrm{t}$ (triplet), $\mathrm{td}$ (triplet of doublets), $\mathrm{q}$ (quartet), and $\mathrm{m}$ (multiplet).

\subsubsection{Synthetic Procedure for Succinamic Acid (1)}

Succinic anhydride (5.0 g, $50 \mathrm{mmol}, 1$ equivalent (eq)) was dissolved in $50 \mathrm{~mL}$ of glacial acetic acid and, afterward, an equimolar amount of DL-phenylglycine $(7.56 \mathrm{~g})$ was added. The reaction mixture was heated at $70{ }^{\circ} \mathrm{C}$ and next stirred for $12 \mathrm{~h}$. After this time, acetic acid was evaporated to dryness. The intermediate $\mathbf{1}$ was obtained as a solid substance after wash up with diethyl ether.

4-((Carboxy(phenyl)methyl)amino)-4-oxobutanoic Acid (1)

White solid. Yield: $92 \%$ (11.54 g); m.p. $199.4-200.6{ }^{\circ} \mathrm{C}$; TLC: $\mathrm{R}_{\mathrm{f}}=0.25\left(\mathrm{~S}_{4}\right)$; UPLC (purity $100 \%$ ): $t_{\mathrm{R}}=2.77 \mathrm{~min}$. LC-MS (ESI): $\mathrm{m} / z$ calculated for $\mathrm{C}_{12} \mathrm{H}_{13} \mathrm{NO}_{5}(\mathrm{M}+\mathrm{H})^{+} 252.08$, found 252.1.

\subsubsection{Synthetic Procedure for Monocarboxylic Acid (2)}

To a suspension of the appropriate succinamic acid 1 ( $45 \mathrm{mmol}, 1 \mathrm{eq})$ in dry benzene $(150 \mathrm{~mL})$, $\mathrm{ZnCl}_{2}(6.13 \mathrm{~g}, 45 \mathrm{mmol}, 1 \mathrm{eq})$ was added, and the mixture was heated to $80^{\circ} \mathrm{C}$. Next, a solution of HMDS (10.89 g, $14.14 \mathrm{~mL}, 67.5 \mathrm{mmol}, 1.5 \mathrm{eq})$ in dry benzene $(15 \mathrm{~mL})$ was added dropwise over $30 \mathrm{~min}$. The reaction mixture was refluxed for an additional $12 \mathrm{~h}$ and concentrated under reduced pressure. After concentration, the residual solid was dissolved in DCM and extracted with $0.1 \mathrm{M} \mathrm{HCl}(3 \times 50 \mathrm{~mL})$, water $(3 \times 50 \mathrm{~mL})$, and saturated brine $(3 \times 50 \mathrm{~mL})$. The organic layer was dried over anhydrous 
$\mathrm{Na}_{2} \mathrm{SO}_{4}$ and then evaporated to dryness. Intermediate 2 was obtained as a solid substance after wash up with diethyl ether.

\section{2-(2,5-Dioxopyrrolidin-1-yl)-2-phenylacetic Acid (2)}

White solid. Yield: 91\% (9.54 g); m.p. 198.3-199.7 ${ }^{\circ} \mathrm{C}$; TLC: $\mathrm{R}_{\mathrm{f}}=0.46\left(\mathrm{~S}_{4}\right)$; UPLC (purity 100\%): $t_{\mathrm{R}}=3.41 \mathrm{~min}$. LC-MS (ESI): $m / z$ calculated for $\mathrm{C}_{12} \mathrm{H}_{11} \mathrm{NO}_{4}(\mathrm{M}+\mathrm{H})^{+}$234.08, found 234.1. ${ }^{1} \mathrm{H}-\mathrm{NMR}$ (300 MHz, DMSO-D 6 ) $\delta 2.73$ (s, 4H, imide), 5.76 (s, 1H, CH-COOH), 7.26-7.35 (m, 3H, ArH) 7.36-7.45 (m, 2H, ArH), 13.22 (br. s, 1H, COOH).

\subsubsection{Synthetic Procedure for Target Compounds (3-31)}

Carbonyldiimidazole $(0.585 \mathrm{~g}, 3.6 \mathrm{mmol}, 1.2 \mathrm{eq})$ was dissolved in $10 \mathrm{~mL}$ of anhydrous DMF. Afterward, the solution was added to intermediate 2 ( $3 \mathrm{mmol}, 1 \mathrm{eq})$ dissolved in $10 \mathrm{~mL}$ of anhydrous DMF (while stirring). After $0.5 \mathrm{~h}$, the appropriate amine ( $3 \mathrm{mmol}, 1 \mathrm{eq}$ ) dissolved in $5 \mathrm{~mL}$ of anhydrous DMF was added dropwise. The mixture was stirred for approximately $24 \mathrm{~h}$ at room temperature and evaporated to dryness. Column chromatography was applied for purification of crude products, using the following developing systems: $S_{1}$ (3-20), $S_{2}$ (21-31). The desired compounds were obtained as solid substances followed by concentration of organic solvents under reduced pressure.

2-(2,5-Dioxopyrrolidin-1-yl)-N,2-diphenylacetamide (3)

White solid, yield: $69.4 \%$, (0.63 g); m.p. $155.8-156.3{ }^{\circ} \mathrm{C}$; TLC: $\mathrm{R}_{\mathrm{f}}=0.52\left(\mathrm{~S}_{1}\right)$; UPLC (purity $>99.9 \%$ ): $t_{\mathrm{R}}=5.46 \mathrm{~min}$. LC-MS (ESI): $\mathrm{m} / z$ calculated for $\mathrm{C}_{18} \mathrm{H}_{16} \mathrm{~N}_{2} \mathrm{O}_{3}(\mathrm{M}+\mathrm{H})^{+} 309.12$, found 309.2 . ${ }^{1} \mathrm{H}-\mathrm{NMR}\left(300 \mathrm{MHz}, \mathrm{CDCl}_{3}\right) \delta 2.74$ (s, 4H, imide), $5.90(\mathrm{~s}, 1 \mathrm{H}, \mathrm{CH}), 7.11$ (d, J = 7.3 Hz, 1H, ArH), 7.24-7.30 (m, 2H, ArH), 7.36-7.46 (m, 5H, ArH), 7.52 (s, 1H, NH), 7.58-7.67 (m, 2H, ArH). ${ }^{13} \mathrm{C}-\mathrm{NMR}$ $\left(75 \mathrm{MHz}_{\mathrm{CDCl}}\right) \delta 28.2,59.2,120.1,124.9,129.0,129.5,129.6,129.9,133.8,137.0,164.8,176.6$. Analysis calculated for $\mathrm{C}_{18} \mathrm{H}_{16} \mathrm{~N}_{2} \mathrm{O}_{3}$ (308.34): C: 70.12, H: 5.23, N: 9.09; found C: 70.25, H: 5.37, N: 9.26.

2-(2,5-Dioxopyrrolidin-1-yl)-N-(2-fluorophenyl)-2-phenylacetamide (4)

White solid, yield: 68.7\%; (0.67 g) m.p. 106.6-107.1 ${ }^{\circ} \mathrm{C}$; TLC: $\mathrm{R}_{\mathrm{f}}=0.51\left(\mathrm{~S}_{1}\right)$; UPLC (purity $>99.9 \%$ ): $t_{\mathrm{R}}=5.52 \mathrm{~min}$. LC-MS (ESI): $\mathrm{m} / z$ calculated for $\mathrm{C}_{18} \mathrm{H}_{15} \mathrm{FN}_{2} \mathrm{O}_{3}(\mathrm{M}+\mathrm{H})^{+}$327.11, found 327.3. ${ }^{1} \mathrm{H}-\mathrm{NMR}$ $\left(300 \mathrm{MHz} \mathrm{CDCl}_{3}\right) \delta 2.78$ (s, 4H, imide), 5.92 (s, 1H, CH), 6.98-7.11 (m, 3H, ArH), 7.42-7.47 (m, 3H, ArH), 7.62-7.68 (m, 3H, ArH, NH), 8.25 (td, $J=7.91,1.76 \mathrm{~Hz}, 1 \mathrm{H}, \mathrm{ArH}) .{ }^{13} \mathrm{C}-\mathrm{NMR}\left(75 \mathrm{MHz}, \mathrm{CDCl}_{3}\right) \delta 28.2$, $59.3,114.8(\mathrm{~d}, J=18.4 \mathrm{~Hz}), 121.7,124.5,125.0,125.1,125.6(\mathrm{~d}, J=10.4 \mathrm{~Hz}), 129.6,129.7-129.9,133.6,152.5$ $(\mathrm{d}, J=243.0 \mathrm{~Hz}), 154.1-154.1,164.7,176.4$. Analysis calculated for $\mathrm{C}_{18} \mathrm{H}_{15} \mathrm{FN}_{2} \mathrm{O}_{3}(326.33)$ : C: 66.25, H: 4.63, N: 8.58; found C: $66.32, \mathrm{H}: 4.71, \mathrm{~N}: 8.79$.

\section{2-(2,5-Dioxopyrrolidin-1-yl)-N-(3-fluorophenyl)-2-phenylacetamide (5)}

White solid, yield: $72.3 \%$, (0.71 g); m.p. $148.2-149.1^{\circ} \mathrm{C}$; TLC: $\mathrm{R}_{\mathrm{f}}=0.55\left(\mathrm{~S}_{1}\right)$; UPLC (purity >99.9\%): $t_{\mathrm{R}}=5.81 \mathrm{~min}$. LC-MS (ESI): $\mathrm{m} / z$ calculated for $\mathrm{C}_{18} \mathrm{H}_{15} \mathrm{FN}_{2} \mathrm{O}_{3}(\mathrm{M}+\mathrm{H})+327.11$, found 327.4. ${ }^{1} \mathrm{H}-\mathrm{NMR}$ $\left(300 \mathrm{MHz} \mathrm{CDCl}_{3}\right) \delta 2.75$ (s, 4H, imide), 5.89 (s, 1H, CH), 6.75-6.83 (m, 1H, ArH), 6.96-7.00 (m, 1H, ArH), $7.20(\mathrm{td}, J=8.2,6.5 \mathrm{~Hz}, 1 \mathrm{H}, \mathrm{ArH}), 7.35-7.45(\mathrm{~m}, 4 \mathrm{H}, \mathrm{ArH}), 7.57-7.62(\mathrm{~m}, 3 \mathrm{H}, \mathrm{ArH}, \mathrm{NH}) .{ }^{13} \mathrm{C}-\mathrm{NMR}$ $\left(75 \mathrm{MHz} \mathrm{CDCl}_{3}\right) \delta 28.2,59.2,107.6(\mathrm{~d}, J=26.5 \mathrm{~Hz}) 111.6(\mathrm{~d}, J=21.9 \mathrm{~Hz}) 115.3(\mathrm{~d}, J=3.5 \mathrm{~Hz}) 129.6,129.7$, $129.8,130.0,130.1,133.6,162.7(\mathrm{~d}, J=246.5 \mathrm{~Hz}) 164.9$, 176.5. Analysis calculated for $\mathrm{C}_{18} \mathrm{H}_{15} \mathrm{FN}_{2} \mathrm{O}_{3}$ (326.33): C: $66.25, \mathrm{H}: 4.63, \mathrm{~N}: 8.58$; found C: $66.09, \mathrm{H}: 4.39, \mathrm{~N}: 8.42$.

\section{2-(2,5-Dioxopyrrolidin-1-yl)-N-(4-fluorophenyl)-2-phenylacetamide (6)}

White solid, yield: 70.6\%, (0.69 g); m.p. $143.4-143.9^{\circ} \mathrm{C}$; TLC: $\mathrm{R}_{\mathrm{f}}=0.48\left(\mathrm{~S}_{1}\right)$; UPLC (purity >99.9\%): $t_{\mathrm{R}}=5.59 \mathrm{~min}$. LC-MS (ESI): $\mathrm{m} / z$ calculated for $\mathrm{C}_{18} \mathrm{H}_{15} \mathrm{FN}_{2} \mathrm{O}_{3}(\mathrm{M}+\mathrm{H})+327.11$, found 327.4. ${ }^{1} \mathrm{H}-\mathrm{NMR}$ $\left(300 \mathrm{MHz} \mathrm{CDCl}_{3}\right) \delta 2.75$ (s, 4H, imide), 5.88 (s, 1H, CH), 6.92-6.99 (m, 2H, ArH), 7.30-7.38 (m, 2H, $\mathrm{ArH}), 7.40-7.46$ (m, 3H, ArH), 7.48 (br. s, 1H, NH), 7.56-7.64 (m, 2H, ArH). ${ }^{13} \mathrm{C}-\mathrm{NMR}\left(75 \mathrm{MHz}, \mathrm{CDCl}_{3}\right)$ 
$\delta 28.2,59.1,114.9-116.3,122.1(\mathrm{~d}, J=8.1 \mathrm{~Hz}), 129.5,129.7,129.8,133.0(\mathrm{~d}, J=3.5 \mathrm{~Hz}), 133.8,159.6(\mathrm{~d}$, $J=244.2 \mathrm{~Hz}$ ) 164.8, 176.6. Analysis calculated for $\mathrm{C}_{18} \mathrm{H}_{15} \mathrm{FN}_{2} \mathrm{O}_{3}$ (326.33): C: 66.25, $\mathrm{H}: 4.63, \mathrm{~N}: 8.58$; found C: $66.31, \mathrm{H}: 4.47, \mathrm{~N}: 8.62$.

N-(2-Chlorophenyl)-2-(2,5-dioxopyrrolidin-1-yl)-2-phenylacetamide (7)

White solid, yield: $64.3 \%$, (0.65 g); m.p. $76.8-78.6{ }^{\circ} \mathrm{C}$; TLC: $\mathrm{R}_{\mathrm{f}}=0.56\left(\mathrm{~S}_{1}\right)$; UPLC (purity $>99.9 \%$ ): $t_{\mathrm{R}}=6.19 \mathrm{~min}$. LC-MS (ESI): $\mathrm{m} / z$ calculated for $\mathrm{C}_{18} \mathrm{H}_{15} \mathrm{ClN}_{2} \mathrm{O}_{3}(\mathrm{M}+\mathrm{H})^{+} 343.08$, found 343.8. ${ }^{1} \mathrm{H}-\mathrm{NMR}$ $\left(300 \mathrm{MHz}, \mathrm{CDCl}_{3}\right) \delta 2.79(\mathrm{~s}, 4 \mathrm{H}$, imide), $5.90(\mathrm{~s}, 1 \mathrm{H}, \mathrm{CH}), 7.01(\mathrm{td}, J=7.7,1.4 \mathrm{~Hz}, 1 \mathrm{H}, \mathrm{ArH})$, 7.20-7.28 (m, 2H, ArH), 7.42-7.50 (m, 3H, ArH), 7.65-7.70 (m, 2H, ArH), 7.92 (br. s, 1H, NH), 8.34 (dd, $J=7.9,1.4 \mathrm{~Hz}, 1 \mathrm{H}, \mathrm{ArH}) .{ }^{13} \mathrm{C}-\mathrm{NMR}\left(75 \mathrm{MHz}, \mathrm{CDCl}_{3}\right) \delta 25.3,28.3,59.4,121.2,123.0,125.2,127.7,128.9$, 129.6, 129.8, 130.0, 133.6, 134.0, 164.8, 176.4. Analysis calculated for $\mathrm{C}_{18} \mathrm{H}_{15} \mathrm{ClN}_{2} \mathrm{O}_{3}$ (342.78): C: 63.07, H: 4.41, N: 8.17; found C: 63.31, H: 4.22, N: 8.25.

$\mathrm{N}$-(3-Chlorophenyl)-2-(2,5-dioxopyrrolidin-1-yl)-2-phenylacetamide (8)

White solid, yield: $72.8 \%$, $\left(0.75\right.$ g); m.p. $109.4-109.9{ }^{\circ} \mathrm{C}$; TLC: $\mathrm{R}_{\mathrm{f}}=0.49\left(\mathrm{~S}_{1}\right)$; UPLC (purity $>99.9 \%$ ): $t_{\mathrm{R}}=6.26 \mathrm{~min}$. LC-MS (ESI): $\mathrm{m} / z$ calculated for $\mathrm{C}_{18} \mathrm{H}_{15} \mathrm{ClN}_{2} \mathrm{O}_{3}(\mathrm{M}+\mathrm{H})^{+} 343.08$, found 343.8. ${ }^{1} \mathrm{H}-\mathrm{NMR}$ $\left(300 \mathrm{MHz}, \mathrm{CDCl}_{3}\right) \delta 2.77(\mathrm{~s}, 4 \mathrm{H}$, imide), $5.89(\mathrm{~s}, 1 \mathrm{H}, \mathrm{CH}), 7.05-7.16(\mathrm{~m}, 1 \mathrm{H}, \mathrm{ArH}), 7.18-7.24(\mathrm{~m}, 2 \mathrm{H}, \mathrm{ArH})$, 7.41-7.46 (m, 3H, ArH), 7.50-7.54 (m, 2H, NH, ArH), 7.57-7.62 (m, 2H, ArH). ${ }^{13} \mathrm{C}-\mathrm{NMR}(75 \mathrm{MHz}$, $\left.\mathrm{CDCl}_{3}\right) \delta 28.2,59.2,118.1,120.2,125.0,129.6,129.8,129.9,133.5,134.6,138.1,164.9,176.5$. Analysis calculated for $\mathrm{C}_{18} \mathrm{H}_{15} \mathrm{ClN}_{2} \mathrm{O}_{3}$ (342.78): C: 63.07, $\mathrm{H}: 4.41, \mathrm{~N}: 8.17$; found $\mathrm{C}: 63.01, \mathrm{H}: 4.69, \mathrm{~N}: 8.24$.

N-(4-Chlorophenyl)-2-(2,5-dioxopyrrolidin-1-yl)-2-phenylacetamide (9)

White solid, yield: $69.6 \%$, $\left(0.72\right.$ g); m.p. $103.8-105.6{ }^{\circ} \mathrm{C}$; TLC: $\mathrm{R}_{\mathrm{f}}=0.54\left(\mathrm{~S}_{1}\right)$; UPLC (purity $>99.9 \%$ ): $t_{\mathrm{R}}=6.16 \mathrm{~min}$. LC-MS (ESI): $\mathrm{m} / \mathrm{z}$ calculated for $\mathrm{C}_{18} \mathrm{H}_{15} \mathrm{ClN}_{2} \mathrm{O}_{3}(\mathrm{M}+\mathrm{H})^{+} 343.08$, found 343.8. ${ }^{1} \mathrm{H}-\mathrm{NMR}$ $\left(300 \mathrm{MHz}, \mathrm{CDCl}_{3}\right) \delta 2.76(\mathrm{~s}, 4 \mathrm{H}$, imide), $5.88(\mathrm{~s}, 1 \mathrm{H}, \mathrm{CH}), 7.20-7.24(\mathrm{~m}, 1 \mathrm{H}, \mathrm{ArH}), 7.25-7.35(\mathrm{~m}, 3 \mathrm{H}, \mathrm{ArH})$, 7.40-7.45 (m, 3H, ArH), 7.52 (s, 1H, NH), 7.57-7.62 (m, 2H, ArH). ${ }^{13} \mathrm{C}-\mathrm{NMR}\left(75 \mathrm{MHz}, \mathrm{CDCl}_{3}\right) \delta 15.3$, 28.2, 59.2, 65.8, 121.4, 129.0, 129.6, 129.7, 129.8, 130.0, 133.7, 135.6, 164.8, 176.5. Analysis calculated for $\mathrm{C}_{18} \mathrm{H}_{15} \mathrm{ClN}_{2} \mathrm{O}_{3}$ (342.78): C: 63.07, H: 4.41, N: 8.17; found C: 63.31, H: 4.34, N: 8.37.

(2-(2,5-Dioxopyrrolidin-1-yl)-2-phenyl- $N$-(2-(trifluoromethyl)phenyl)acetamide) (10)

White solid, yield: $71.1 \%,\left(0.80\right.$ g); m.p. $162.2-163.4^{\circ} \mathrm{C}$; TLC: $\mathrm{R}_{\mathrm{f}}=0.58\left(\mathrm{~S}_{1}\right)$; UPLC (purity $>99.9 \%$ ): $t_{\mathrm{R}}=6.59 \mathrm{~min}$. LC-MS (ESI): $\mathrm{m} / z$ calculated for $\mathrm{C}_{19} \mathrm{H}_{15} \mathrm{~F}_{3} \mathrm{~N}_{2} \mathrm{O}_{3}(\mathrm{M}+\mathrm{H})^{+} 377.10$, found 377.5. ${ }^{1} \mathrm{H}-\mathrm{NMR}$ $\left(300 \mathrm{MHz}, \mathrm{CDCl}_{3}\right) \delta 2.79(\mathrm{~s}, 4 \mathrm{H}$, imide), $5.98(\mathrm{~s}, 1 \mathrm{H}, \mathrm{CH}), 7.32-7.38(\mathrm{~m}, 3 \mathrm{H}, \mathrm{ArH}), 7.42-7.49(\mathrm{~m}, 4 \mathrm{H}, \mathrm{ArH})$, 7.51-7.62 (m, 2H, ArH), $7.78(\mathrm{~s}, 1 \mathrm{H}, \mathrm{NH}) .{ }^{13} \mathrm{C}-\mathrm{NMR}\left(75 \mathrm{MHz} \mathrm{CDCl}_{3}\right) \delta 27.8,59.4,116.2(\mathrm{~d}, J=271.8 \mathrm{~Hz})$, $118.3,124.7(\mathrm{q}, J=32.3 \mathrm{~Hz}), 126.3(\mathrm{q}, J=4.2 \mathrm{~Hz}) 128.2,128.9,129.4,132.1,140.3,163.2,177.4$. Analysis calculated for $\mathrm{C}_{19} \mathrm{H}_{15} \mathrm{~F}_{3} \mathrm{~N}_{2} \mathrm{O}_{3}$ (376.34): C: 60.64, $\mathrm{H}: 4.02, \mathrm{~N}: 7.44$; found C: 60.44, H: 4.42, N: 7.28.

2-(2,5-Dioxopyrrolidin-1-yl)-2-phenyl- $N$-(3-(trifluoromethyl)phenyl)acetamide (11)

White solid, yield: $68.9 \%$, (0.78 g); m.p. $158.2-159.4{ }^{\circ} \mathrm{C}$; TLC: $\mathrm{R}_{\mathrm{f}}=0.60\left(\mathrm{~S}_{1}\right)$; UPLC (purity $>99.9 \%$ ): $t_{\mathrm{R}}=6.52 \mathrm{~min}$. LC-MS (ESI): $\mathrm{m} / z$ calculated for $\mathrm{C}_{19} \mathrm{H}_{15} \mathrm{~F}_{3} \mathrm{~N}_{2} \mathrm{O}_{3}(\mathrm{M}+\mathrm{H})^{+}$377.10, found 377.5. ${ }^{1} \mathrm{H}-\mathrm{NMR}$ $\left(300 \mathrm{MHz}, \mathrm{CDCl}_{3}\right) \delta 2.77(\mathrm{~s}, 4 \mathrm{H}$, imide), $5.92(\mathrm{~s}, 1 \mathrm{H}, \mathrm{CH}), 7.38(\mathrm{~d}, J=10.3 \mathrm{~Hz}, 1 \mathrm{H}, \mathrm{ArH}), 7.37(\mathrm{~s}, 1 \mathrm{H}, \mathrm{ArH})$, 7.41-7.47 (m, 3H, ArH), 7.55-7.66 (m, 4H, ArH), $7.70(\mathrm{~s}, 1 \mathrm{H}, \mathrm{NH}){ }^{13} \mathrm{C}-\mathrm{NMR}\left(75 \mathrm{MHz}, \mathrm{CDCl}_{3}\right) \delta 28.2$, 59.2, 116.8, 116.8-116.9, $121.5(\mathrm{q}, J=3.5 \mathrm{~Hz}), 123.7(\mathrm{~d}, J=272.9 \mathrm{~Hz}), 123.2,129.5,129.6,129.8,129.8$, $131.4(\mathrm{q}, J=33.0 \mathrm{~Hz}), 133.5,137.5,165.1,176.5$. Analysis calculated for $\mathrm{C}_{19} \mathrm{H}_{15} \mathrm{~F}_{3} \mathrm{~N}_{2} \mathrm{O}_{3}$ (376.34): C: 60.64, H: 4.02, N: 7.44; found C: 60.51, H: 4.27, N: 7.31.

2-(2,5-Dioxopyrrolidin-1-yl)-2-phenyl- $N$-(4-(trifluoromethyl)phenyl)acetamide (12)

White solid, yield: $73.1 \%$, (0.82 g); m.p. $188.1-188.5^{\circ} \mathrm{C}$; TLC: $\mathrm{R}_{\mathrm{f}}=0.58\left(\mathrm{~S}_{1}\right)$; UPLC (purity >99.9\%): $t_{\mathrm{R}}=6.59 \mathrm{~min}$. LC-MS (ESI): $\mathrm{m} / z$ calculated for $\mathrm{C}_{19} \mathrm{H}_{15} \mathrm{~F}_{3} \mathrm{~N}_{2} \mathrm{O}_{3}(\mathrm{M}+\mathrm{H})^{+} 377.10$, found 377.5. ${ }^{1} \mathrm{H}-\mathrm{NMR}$ 
$\left(300 \mathrm{MHz}, \mathrm{CDCl}_{3}\right) \delta 2.77$ (s, 4H, imide), $5.92(\mathrm{~s}, 1 \mathrm{H}, \mathrm{CH}), 7.42-7.47(\mathrm{~m}, 3 \mathrm{H}, \mathrm{ArH}), 7.48-7.53(\mathrm{~m}, 4 \mathrm{H}, \mathrm{ArH})$, 7.58-7.63 (m, 2H, ArH), $7.69(\mathrm{~s}, 1 \mathrm{H}, \mathrm{NH}) .{ }^{13} \mathrm{C}-\mathrm{NMR}\left(75 \mathrm{MHz}, \mathrm{CDCl}_{3}\right) \delta 28.2,59.2,118.5(\mathrm{~d}, J=271.8 \mathrm{~Hz})$, 119.7, $126.1(\mathrm{q}, J=32.3 \mathrm{~Hz}), 126.2(\mathrm{q}, J=4.2 \mathrm{~Hz}) 129.6,129.7,129.8,133.5,140.0,165.1,176.5$. Analysis calculated for $\mathrm{C}_{19} \mathrm{H}_{15} \mathrm{~F}_{3} \mathrm{~N}_{2} \mathrm{O}_{3}$ (376.34): C: 60.64, $\mathrm{H}: 4.02, \mathrm{~N}: 7.44$; found $\mathrm{C}: 60.52, \mathrm{H}: 4.34, \mathrm{~N}: 7.31$.

2-(2,5-Dioxopyrrolidin-1-yl)-2-phenyl-N-(3-(trifluoromethoxy)phenyl)acetamide (13)

White solid, yield: $68.7 \%$, (0.79 g); m.p. $132.6-133.4^{\circ} \mathrm{C}$; TLC: $\mathrm{R}_{\mathrm{f}}=0.66\left(\mathrm{~S}_{2}\right)$; UPLC (purity $>99.9 \%$ ): $t_{\mathrm{R}}=6.76 \mathrm{~min}$. LC-MS (ESI): $\mathrm{m} / \mathrm{z}$ calculated for $\mathrm{C}_{19} \mathrm{H}_{15} \mathrm{~F}_{3} \mathrm{~N}_{2} \mathrm{O}_{4}(\mathrm{M}+\mathrm{H})^{+}$393.10, found 393.2. ${ }^{1} \mathrm{H}-\mathrm{NMR}$ $\left(500 \mathrm{MHz}, \mathrm{CDCl}_{3}\right) \delta 2.77$ (s, 4H, imide), $5.88(\mathrm{~s}, 1 \mathrm{H}, \mathrm{CH}), 5.98$ (br. s, 1H, NH), 7.09-7.12 (m, 2H, ArH), $7.18(\mathrm{~d}, J=8.0 \mathrm{~Hz}, 1 \mathrm{H}, \mathrm{ArH}), 7.33-7.43(\mathrm{~m}, 4 \mathrm{H}, \mathrm{ArH}), 7.59-7.62(\mathrm{~m}, 2 \mathrm{H}, \mathrm{ArH}) .{ }^{13} \mathrm{C}-\mathrm{NMR}(126 \mathrm{MHz}$, $\left.\mathrm{CDCl}_{3}\right) \delta 27.5,56.2,118.2,120.2,120.8(\mathrm{q}, J=257.1 \mathrm{~Hz}), 124.3,127.2,128.8,129.9,130.8,132.4,141.7$, 147.2, 166.2, 175.7. Analysis calculated for $\mathrm{C}_{19} \mathrm{H}_{15} \mathrm{~F}_{3} \mathrm{~N}_{2} \mathrm{O}_{4}$ (392.33): C: $58.17, \mathrm{H}: 3.85, \mathrm{~N}: 7.14$, found C: 58.43, H: 3.98, N: 7.03 .

N-Benzyl-2-(2,5-dioxopyrrolidin-1-yl)-2-phenylacetamide (14)

White solid, yield: $71.2 \%$, (0.69 g); m.p. $128.3-129.9^{\circ} \mathrm{C}$; TLC: $\mathrm{R}_{\mathrm{f}}=0.45\left(\mathrm{~S}_{1}\right)$; UPLC (purity $>99 \%$ ): $t_{\mathrm{R}}=5.24 \mathrm{~min}$. LC-MS (ESI): $\mathrm{m} / z$ calculated for $\mathrm{C}_{19} \mathrm{H}_{18} \mathrm{~N}_{2} \mathrm{O}_{3}(\mathrm{M}+\mathrm{H})^{+} 323.13$, found 323.3. ${ }^{1} \mathrm{H}-\mathrm{NMR}$ $\left(300 \mathrm{MHz}, \mathrm{CDCl}_{3}\right): \delta 2.77\left(\mathrm{~s}, 4 \mathrm{H}\right.$, imide), $4.35-4.44\left(\mathrm{~m}, 1 \mathrm{H}, \mathrm{CH}_{2}\right), 4.51-4.61\left(\mathrm{~m}, 1 \mathrm{H}, \mathrm{CH}_{2}\right), 5.77(\mathrm{~s}, 1 \mathrm{H}, \mathrm{CH})$, 5.96 (br. s, $1 \mathrm{H}, \mathrm{NH}), 7.22-7.40$ (m, 5H, ArH), 7.54-7.64 (m, 5H, ArH). ${ }^{13} \mathrm{C}-\mathrm{NMR}\left(75 \mathrm{MHz}, \mathrm{CDCl}_{3}\right)$ : $\delta 28.2,43.9,58.5,76.8,77.5,127.1,127.5,128.4,130.3,134.1,137.6,166.5,176.4$. Analysis calculated for $\mathrm{C}_{19} \mathrm{H}_{18} \mathrm{~N}_{2} \mathrm{O}_{3}$ (322.36): C: 70.79, H: 5.63, N: 8.69; found C: 70.89, H: 5.61, N: 8.72.

2-(2,5-Dioxopyrrolidin-1-yl)- $N$-(2-fluorobenzyl)-2-phenylacetamide (15)

White solid, yield: $74.5 \%$, (0.76 g); mp. $148.3-149.3{ }^{\circ} \mathrm{C}$; TLC: $\mathrm{R}_{\mathrm{f}}=0.55\left(\mathrm{~S}_{1}\right)$; UPLC (purity $>99,9 \%$ ): $t_{\mathrm{R}}=5.36 \mathrm{~min}$. LC-MS (ESI): $\mathrm{m} / z$ calculated for $\mathrm{C}_{19} \mathrm{H}_{17} \mathrm{~N}_{2} \mathrm{O}_{3} \mathrm{~F}(\mathrm{M}+\mathrm{H})^{+} 341.12$, found 341.13. ${ }^{1} \mathrm{H}-\mathrm{NMR}\left(300 \mathrm{MHz}, \mathrm{CDCl}_{3}\right): \delta 2.75(\mathrm{~s}, 4 \mathrm{H}$, imide), 4.50 (dd, $J=5.7,4.1 \mathrm{~Hz}$, $\left.2 \mathrm{H}, \mathrm{CH}_{2}\right), 5.74(\mathrm{~s}, 1 \mathrm{H}, \mathrm{CH}), 6.02($ br. s, $1 \mathrm{H}, \mathrm{NH}), 6.94-7.03(\mathrm{~m}, 1 \mathrm{H}, \mathrm{ArH}), 7.07-7.15(\mathrm{~m}, 1 \mathrm{H}, \mathrm{ArH})$, 7.19-7.28 (m, 1H, ArH), 7.33-7.41 (m, 4H, ArH), 7.54-7.59 (m, 2H, ArH). ${ }^{13} \mathrm{C}-\mathrm{NMR}\left(75 \mathrm{MHz}, \mathrm{CDCl}_{3}\right)$ : $\delta 28.2,38.0(\mathrm{~d}, J=4.6 \mathrm{~Hz}), 58.5,115.1,115.4,124.3,124.5,124.7,129.3(\mathrm{~d}, J=8.1 \mathrm{~Hz}), 129.4,129.5,129.9$, 134.1, $160.7(\mathrm{dd}, J=249.9,1.0 \mathrm{~Hz}), 166.7,176.5$. Analysis calculated for $\mathrm{C}_{19} \mathrm{H}_{17} \mathrm{~N}_{2} \mathrm{O}_{3} \mathrm{~F}$ (340.35): C: 67.05, H: 5.03, N: 5.58; found C: 67.01, H: 5.36, N: 5.29.

2-(2,5-Dioxopyrrolidin-1-yl)- $N$-(3-fluorobenzyl)-2-phenylacetamide (16)

White solid, yield: $69.4 \%$, $(0.71 \mathrm{~g})$; m.p. $136.7-137.7^{\circ} \mathrm{C}$; TLC: $\mathrm{R}_{\mathrm{f}}=0.49\left(\mathrm{~S}_{1}\right)$; UPLC (purity $>99.9 \%$ ): $t_{\mathrm{R}}=5.40 \mathrm{~min}$. LC-MS (ESI): $\mathrm{m} / \mathrm{z}$ calculated for $\mathrm{C}_{19} \mathrm{H}_{17} \mathrm{~N}_{2} \mathrm{O}_{3} \mathrm{~F}(\mathrm{M}+\mathrm{H})^{+} 341.12$, found 341.3. ${ }^{1} \mathrm{H}-\mathrm{NMR}$ $\left(300 \mathrm{MHz}, \mathrm{CDCl}_{3}\right): \delta 2.77\left(\mathrm{~s}, 4 \mathrm{H}\right.$, imide) $4.52\left(\mathrm{dd}, J=15.4,5.6 \mathrm{~Hz}, 2 \mathrm{H}, \mathrm{CH}_{2}\right), 5.76(\mathrm{~s}, 1 \mathrm{H}, \mathrm{CH})$, 5.98 (br. s, $1 \mathrm{H}, \mathrm{NH}), 6.90-7.05(\mathrm{~m}, 3 \mathrm{H}, \mathrm{ArH}), 7.23-7.32(\mathrm{~m}, 1 \mathrm{H}, \mathrm{ArH}), 7.35-7.42(\mathrm{~m}, 3 \mathrm{H}, \mathrm{ArH})$, 7.56-7.61 (m, 2H, ArH). ${ }^{13} \mathrm{C}-\mathrm{NMR}\left(75 \mathrm{MHz}, \mathrm{CDCl}_{3}\right): \delta 28.2,43.4,58.5,114.3(\mathrm{~d}, J=23.0 \mathrm{~Hz}), 114.4(\mathrm{~d}$, $J=20.7 \mathrm{~Hz}), 122.8,129.7(\mathrm{~d}, J=28.8 \mathrm{~Hz}), 129.5,130.2(\mathrm{~d}, J=9.2 \mathrm{~Hz}), 134.1,140.3(\mathrm{~d}, J=6.9 \mathrm{~Hz}), 163.0(\mathrm{~d}$, $J=246.5 \mathrm{~Hz}), 166.8,176.5$. Analysis calculated for $\mathrm{C}_{19} \mathrm{H}_{17} \mathrm{~N}_{2} \mathrm{O}_{3} \mathrm{~F}$ (340.35): C: 67.05, H: 5.03, N: 5.58; found C: $67.19, \mathrm{H}: 5.22, \mathrm{~N}: 5.66$.

2-(2,5-Dioxopyrrolidin-1-yl)-N-(4-fluorobenzyl)-2-phenylacetamide (17)

White solid, yield: $65.7 \%$, (0.67 g); mp. $146.3-147.7^{\circ} \mathrm{C}$; TLC: $\mathrm{R}_{\mathrm{f}}=0.45\left(\mathrm{~S}_{1}\right)$; UPLC (purity >99.9\%): $t_{\mathrm{R}}=5.39 \mathrm{~min}$. LC-MS (ESI): $\mathrm{m} / z$ calculated for $\mathrm{C}_{19} \mathrm{H}_{17} \mathrm{~N}_{2} \mathrm{O}_{3} \mathrm{~F}(\mathrm{M}+\mathrm{H})^{+} 341.12$, found 341.1. ${ }^{1} \mathrm{H}-\mathrm{NMR}$ $\left(300 \mathrm{MHz}, \mathrm{CDCl}_{3}\right): \delta 2.76\left(\mathrm{~s}, 4 \mathrm{H}\right.$, imide), $4.31\left(\mathrm{dd}, J=15.0,5.5 \mathrm{~Hz}, 2 \mathrm{H}, \mathrm{CH}_{2}\right), 5.75(\mathrm{~s}, 1 \mathrm{H}, \mathrm{CH})$, 5.95 (br. s, 1H, NH), 6.95-7.03 (m, 2H, ArH), 7.18-7.27 (m, 2H, ArH), 7.34-7.40 (m, 3H, ArH), 7.52-7.59 (m, 2H, ArH). ${ }^{13} \mathrm{C}-\mathrm{NMR}\left(75 \mathrm{MHz}, \mathrm{CDCl}_{3}\right): \delta 28.2,43.2,58.5,115.5(\mathrm{~d}, J=21.9 \mathrm{~Hz}), 129.1$ (d, 
$J=8.1 \mathrm{~Hz}), 129.4,129.9,133.5(\mathrm{~d}, J=3.5 \mathrm{~Hz}), 134.2,162.1(\mathrm{~d}, J=246.5 \mathrm{~Hz}), 166.6,176.5$. Analysis calculated for $\mathrm{C}_{19} \mathrm{H}_{17} \mathrm{~N}_{2} \mathrm{O}_{3} \mathrm{~F}$ (340.35): C: 67.05, H: 5.03, N: 5.58; found C: 67.18, H: 5.29, N: 5.41.

N-(2-Chlorobenzyl)-2-(2,5-dioxopyrrolidin-1-yl)-2-phenylacetamide (18)

White solid, yield: $66.3 \%$, (0.71 g); m.p. $152.0-153.6^{\circ} \mathrm{C}$; TLC: $\mathrm{R}_{\mathrm{f}}=0.55\left(\mathrm{~S}_{1}\right)$; UPLC (purity $97 \%$ ): $t_{\mathrm{R}}=5.79 \mathrm{~min}$. LC-MS (ESI): $\mathrm{m} / \mathrm{z}$ calculated for $\mathrm{C}_{19} \mathrm{H}_{17} \mathrm{~N}_{2} \mathrm{O}_{3} \mathrm{Cl}(\mathrm{M}+\mathrm{H})^{+}$357.09, found 357.1. ${ }^{1} \mathrm{H}-\mathrm{NMR}$ $\left(300 \mathrm{MHz}, \mathrm{CDCl}_{3}\right): \delta 2.75$ (s, $4 \mathrm{H}$, imide), $4.53\left(\mathrm{dd}, J=6.1,2.4 \mathrm{~Hz}, 2 \mathrm{H}, \mathrm{CH}_{2}\right), 5.74(\mathrm{~s}, 1 \mathrm{H}, \mathrm{CH}), 6.11$ (br. s, $1 \mathrm{H}$, $\mathrm{NH}), 7.16-7.28(\mathrm{~m}, 2 \mathrm{H}, \mathrm{ArH}), 7.29-7.34(\mathrm{~m}, 1 \mathrm{H}, \mathrm{ArH}), 7.35-7.43(\mathrm{~m}, 4 \mathrm{H}, \mathrm{ArH}), 7.54-7.60(\mathrm{~m}, 2 \mathrm{H}, \mathrm{ArH})$. ${ }^{13} \mathrm{C}-\mathrm{NMR}\left(75 \mathrm{MHz}, \mathrm{CDCl}_{3}\right): \delta 28.2,42.0,58.5,76.4,78.1,127.1,128.4,130.0,133.3,134.1,134.9,166.6$, 176.4. Analysis calculated for $\mathrm{C}_{19} \mathrm{H}_{17} \mathrm{~N}_{2} \mathrm{O}_{3} \mathrm{Cl}$ (356.81): C: 63.96, $\mathrm{H}: 4.80, \mathrm{~N}: 7.85$; found C: 63.91, $\mathrm{H}: 4.65$, N: 7.92.

N-(3-Chlorobenzyl)-2-(2,5-dioxopyrrolidin-1-yl)-2-phenylacetamide (19)

White solid, yield: $79.2 \%$, (0.85 g); m.p. $137.3-138.8^{\circ} \mathrm{C}$; TLC: $\mathrm{R}_{\mathrm{f}}=0.7\left(\mathrm{~S}_{1}\right)$; UPLC (purity 99.5\%): $t_{\mathrm{R}}=5.87 \mathrm{~min}$. LC-MS (ESI): $\mathrm{m} / \mathrm{z}$ calculated for $\mathrm{C}_{19} \mathrm{H}_{17} \mathrm{~N}_{2} \mathrm{O}_{3} \mathrm{Cl}(\mathrm{M}+\mathrm{H})^{+}$357.09, found 357.1. ${ }^{1} \mathrm{H}-\mathrm{NMR}$ $\left(300 \mathrm{MHz}, \mathrm{CDCl}_{3}\right): \delta 2.76\left(\mathrm{~s}, 4 \mathrm{H}\right.$, imide), 4.28-4.58 (m, 2H, $\left.\mathrm{CH}_{2}\right), 5.76(\mathrm{~s}, 1 \mathrm{H}, \mathrm{CH}), 5.99$ (br. $\mathrm{s}, 1 \mathrm{H}$, $\mathrm{NH})$, 7.12-7.18 (m, 1H, ArH), 7.20-7.28 (m, 3H, ArH), 7.35-7.41 (m, 3H, ArH), 7.55-7.61 (m, 2H, ArH). ${ }^{13} \mathrm{C}-\mathrm{NMR}\left(75 \mathrm{MHz}, \mathrm{CDCl}_{3}\right.$ ): $\delta$ 28.2, 43.3, 58.5, 77.3-78.1, 125.5, 127.5 (d, $\left.J=9.2 \mathrm{~Hz}\right), 129.3-130.4$, 133.8-134.6, 139.7, 166.7, 176.4. Analysis calculated for $\mathrm{C}_{19} \mathrm{H}_{17} \mathrm{~N}_{2} \mathrm{O}_{3} \mathrm{Cl}$ (356.81): C: 63.96, $\mathrm{H}: 4.80, \mathrm{~N}$ : 7.85; found C: $63.88, \mathrm{H}: 4.62, \mathrm{~N}: 7.81$.

$\mathrm{N}$-(4-Chlorobenzyl)-2-(2,5-dioxopyrrolidin-1-yl)-2-phenylacetamide (20)

White solid, yield: $75.7 \%$, (0.81 g); m.p. $146.3-147.9^{\circ} \mathrm{C}$; TLC: $\mathrm{R}_{\mathrm{f}}=0.7\left(\mathrm{~S}_{1}\right)$; UPLC (purity 96.5\%): $t_{\mathrm{R}}=5.91 \mathrm{~min}$. LC-MS (ESI): $\mathrm{m} / \mathrm{z}$ calculated for $\mathrm{C}_{19} \mathrm{H}_{17} \mathrm{~N}_{2} \mathrm{O}_{3} \mathrm{Cl}(\mathrm{M}+\mathrm{H})^{+} 357.09$, found 357. ${ }^{1} \mathrm{H}-\mathrm{NMR}$ (300 MHz, $\left.\mathrm{CDCl}_{3}\right): \delta 2.76$ (s, 4H, imide), $4.30\left(\mathrm{dd}, J=15.2,5.4 \mathrm{~Hz}, 1 \mathrm{H}, \mathrm{CH}_{2}\right), 4.55(\mathrm{dd}, J=15.2,6.6 \mathrm{~Hz}$, $\left.1 \mathrm{H}, \mathrm{CH}_{2}\right), 5.75(\mathrm{~s}, 1 \mathrm{H}, \mathrm{CH}), 5.95$ (br. s, $\left.1 \mathrm{H}, \mathrm{NH}\right), 7.16-7.22(\mathrm{~m}, 2 \mathrm{H}, \mathrm{ArH}), 7.25-7.30(\mathrm{~m}, 2 \mathrm{H}, \mathrm{ArH})$, 7.34-7.40 (m, 3H, ArH), 7.54-7.59 (m, $2 \mathrm{H}, \mathrm{ArH}) .{ }^{13} \mathrm{C}-\mathrm{NMR}\left(75 \mathrm{MHz}, \mathrm{CDCl}_{3}\right): \delta 28.2,43.2,58.5,77.3-78.1$, $128.8(\mathrm{~d}, J=2.3 \mathrm{~Hz}), 129.2-130.0,133.3,134.1,136.2,166.6,176.4$. Analysis calculated for $\mathrm{C}_{19} \mathrm{H}_{17} \mathrm{~N}_{2} \mathrm{O}_{3} \mathrm{Cl}$ (356.81): C: 63.96, H: 4.80, N: 7.85; found C: 63.81, H: 4.92, N: 7.67.

2-(2,5-Dioxopyrrolidin-1-yl)-2-phenyl- $N$-(2-(trifluoromethyl)benzyl)acetamide (21)

White solid, yield: $67.1 \%$, (0.78 g); m.p. $137.7-139.1{ }^{\circ} \mathrm{C}$; TLC: $\mathrm{R}_{\mathrm{f}}=0.58\left(\mathrm{~S}_{2}\right)$; UPLC (purity 97\%): $t_{\mathrm{R}}=6.17 \mathrm{~min}$. LC-MS (ESI): $\mathrm{m} / z$ calculated for $\mathrm{C}_{20} \mathrm{H}_{17} \mathrm{~N}_{2} \mathrm{O}_{3} \mathrm{~F}_{3}(\mathrm{M}+\mathrm{H})^{+} 391.12$, found 391.1. ${ }^{1} \mathrm{H}-\mathrm{NMR}$ $\left(300 \mathrm{MHz}, \mathrm{CDCl}_{3}\right): \delta 2.76\left(\mathrm{~s}, 4 \mathrm{H}\right.$, imide) $4.60\left(\mathrm{dd}, J=5.9 \mathrm{~Hz}, 1 \mathrm{H}, \mathrm{CH}_{2}\right) 4.66\left(\mathrm{dd}, J=6.7 \mathrm{~Hz}, 1 \mathrm{H}, \mathrm{CH}_{2}\right)$ $5.74(\mathrm{~s}, 1 \mathrm{H}, \mathrm{CH}) 6.01$ (br. s, 1H, NH) 7.33-7.42 (m, 4H, ArH) 7.51-7.63 (m, 5H, ArH). ${ }^{13} \mathrm{C}-\mathrm{NMR}(75 \mathrm{MHz}$, $\left.\mathrm{CDCl}_{3}\right): \delta 28.2,40.7(\mathrm{~d}, J=2.3 \mathrm{~Hz}), 58.5,124.2(\mathrm{~d}, J=249.9 \mathrm{~Hz}), 125.9(\mathrm{~d}, J=5.8 \mathrm{~Hz}), 126.1(\mathrm{~d}, J=5.8 \mathrm{~Hz})$, 127.6, 129.4, 129.5, 129.8, 130.2, 132.4, 134.0, 166.8, 176.5. Analysis calculated for $\mathrm{C}_{20} \mathrm{H}_{17} \mathrm{~N}_{2} \mathrm{O}_{3} \mathrm{~F}_{3}(390.36)$ : C: $61.54, \mathrm{H}: 4.39, \mathrm{~N}: 7.18$; found C: 61.47, H: 4.21, N: 7.25.

2-(2,5-Dioxopyrrolidin-1-yl)-2-phenyl- $N$-(3-(trifluoromethyl)benzyl)acetamide (22)

White solid, yield: $71.4 \%$, (0.84); m.p. $152.8-153.4{ }^{\circ} \mathrm{C}$; TLC: $\mathrm{R}_{\mathrm{f}}=0.54\left(\mathrm{~S}_{2}\right)$; UPLC (purity $98 \%$ ): $t_{\mathrm{R}}=6.19 \mathrm{~min}$. LC-MS (ESI): $\mathrm{m} / \mathrm{z}$ calculated for $\mathrm{C}_{20} \mathrm{H}_{17} \mathrm{~N}_{2} \mathrm{O}_{3} \mathrm{~F}_{3}(\mathrm{M}+\mathrm{H})^{+}$391.12, found 391.0. ${ }^{1} \mathrm{H}-\mathrm{NMR}$ $\left(300 \mathrm{MHz}, \mathrm{CDCl}_{3}\right): \delta 2.78\left(\mathrm{~s}, 4 \mathrm{H}\right.$, imide) $4.39\left(\mathrm{dd}, J=15.4,5.4 \mathrm{~Hz}, 1 \mathrm{H}, \mathrm{CH}_{2}\right) 4.65(\mathrm{dd}, J=15.4$, $\left.6.7 \mathrm{~Hz}, 1 \mathrm{H}, \mathrm{CH}_{2}\right) 5.78(\mathrm{~s}, 1 \mathrm{H}, \mathrm{CH}) 6.02($ br. s, $1 \mathrm{H}, \mathrm{NH}) 7.35-7.41(\mathrm{~m}, 1 \mathrm{H}, \mathrm{ArH}) 7.42-7.51(\mathrm{~m}, 4 \mathrm{H}, \mathrm{ArH})$ 7.52-7.63 (m, 4H, ArH). ${ }^{13} \mathrm{C}-\mathrm{NMR}\left(75 \mathrm{MHz}, \mathrm{CDCl}_{3}\right): \delta 28.2,43.4,58.5,124.0(\mathrm{~d}, J=272.9 \mathrm{~Hz}), 124.1(\mathrm{q}$, $J=3.8 \mathrm{~Hz}) 124.3(\mathrm{q}, J=3.5 \mathrm{~Hz}), 129.4(\mathrm{~d}, J=27.6 \mathrm{~Hz}), 129.7(\mathrm{~d}, J=25.3 \mathrm{~Hz}), 132.4(\mathrm{~d}, J=249.9 \mathrm{~Hz})$, 138.8, 166.9, 176.5. Analysis calculated for $\mathrm{C}_{20} \mathrm{H}_{17} \mathrm{~N}_{2} \mathrm{O}_{3} \mathrm{~F}_{3}$ (390.36): C: 61.54, H: 4.39, N:7.18; found C: 61.32, H: 4.48, N: 7.02. 
2-(2,5-Dioxopyrrolidin-1-yl)-2-phenyl- $N$-(4-(trifluoromethyl)benzyl)acetamide (23)

White solid, yield: $62.9 \%$, $\left(0.74\right.$ g); m.p. $174.5-176.0^{\circ} \mathrm{C}$; TLC: $\mathrm{R}_{\mathrm{f}}=0.86\left(\mathrm{~S}_{2}\right)$; UPLC (purity $98 \%$ ): $t_{\mathrm{R}}=6.25 \mathrm{~min}$. LC-MS (ESI): $\mathrm{m} / z$ calculated for $\mathrm{C}_{20} \mathrm{H}_{17} \mathrm{~N}_{2} \mathrm{O}_{3} \mathrm{~F}_{3}(\mathrm{M}+\mathrm{H})^{+}$391.12, found 391.1. ${ }^{1} \mathrm{H}-\mathrm{NMR}$ (300 MHz, $\left.\mathrm{CDCl}_{3}\right): \delta 2.77$ (s, $4 \mathrm{H}$, imide), $4.37\left(\mathrm{dd}, J=15.6,5.4 \mathrm{~Hz}, 1 \mathrm{H}, \mathrm{CH}_{2}\right), 4.66(\mathrm{dd}, J=15.6,6.8 \mathrm{~Hz}$, $\left.1 \mathrm{H}, \mathrm{CH}_{2}\right), 5.77(\mathrm{~s}, 1 \mathrm{H}, \mathrm{CH}) 6.03$ (br. s, $\left.1 \mathrm{H}, \mathrm{NH}\right), 7.35-7.44(\mathrm{~m}, 5 \mathrm{H}, \mathrm{ArH}), 7.55-7.61(\mathrm{~m}, 4 \mathrm{H}, \mathrm{ArH})$. ${ }^{13} \mathrm{C}-\mathrm{NMR}\left(75 \mathrm{MHz}, \mathrm{CDCl}_{3}\right): \delta 28.2,43.4,58.5,124.1(\mathrm{~d}, J=271.8 \mathrm{~Hz}), 125.6(\mathrm{~d}, J=11.5 \mathrm{~Hz}), 125.6(\mathrm{~d}$, $J=4.6 \mathrm{~Hz}), 127.6,129.5,129.8,134.1,141.8,166.9,176.5$. Analysis calculated for $\mathrm{C}_{20} \mathrm{H}_{17} \mathrm{~N}_{2} \mathrm{O}_{3} \mathrm{~F}_{3}(390.36)$ : C: $61.54, \mathrm{H}: 4.39, \mathrm{~N}: 7.18$; found C: $61.49, \mathrm{H}: 4.21, \mathrm{~N}: 7.24$.

\section{2-(2,5-Dioxopyrrolidin-1-yl)-2-phenyl- $N$-(3-(trifluoromethoxy)benzyl)acetamide (24)}

White solid, yield: $67.4 \%,\left(0.82\right.$ g); m.p. $129.6-130.4{ }^{\circ} \mathrm{C}$; TLC: $\mathrm{R}_{\mathrm{f}}=0.64\left(\mathrm{~S}_{2}\right)$; UPLC (purity $>99.9 \%$ ): $t_{\mathrm{R}}=6.41 \mathrm{~min}$. LC-MS (ESI): $\mathrm{m} / z$ calculated for $\mathrm{C}_{20} \mathrm{H}_{17} \mathrm{~F}_{3} \mathrm{~N}_{2} \mathrm{O}_{4}(\mathrm{M}+\mathrm{H})^{+}$407.11, found 407.2. ${ }^{1} \mathrm{H}-\mathrm{NMR}$ $\left(500 \mathrm{MHz}, \mathrm{CDCl}_{3}\right) \delta 2.75$ (s, 4H, imide), $4.34\left(\mathrm{dd}, J=15.5,5.7 \mathrm{~Hz}, 1 \mathrm{H}, \mathrm{CH}_{2}\right), 4.59(\mathrm{dd}, J=15.5,6.9 \mathrm{~Hz}$, $\left.1 \mathrm{H}, \mathrm{CH}_{2}\right), 5.75(\mathrm{~s}, 1 \mathrm{H}, \mathrm{CH}), 6.00$ (br. s, $\left.1 \mathrm{H}, \mathrm{NH}\right), 7.07-7.11(\mathrm{~m}, 2 \mathrm{H}, \mathrm{ArH}), 7.20(\mathrm{~d}, J=8.0 \mathrm{~Hz}, 1 \mathrm{H}, \mathrm{ArH})$, 7.31-7.39 (m, 4H, ArH), 7.56-7.58 (m, 2H, ArH). ${ }^{13} \mathrm{C}-\mathrm{NMR}\left(126 \mathrm{MHz}, \mathrm{CDCl}_{3}\right) \delta 28.3,43.4,58.6,120.5(\mathrm{q}$, $J=257.1 \mathrm{~Hz}), 119.9,120.0,125.8,129.6,129.6,129.9,130.2,134.2,140.2,149.5,166.9,176.6$. Analysis calculated for $\mathrm{C}_{20} \mathrm{H}_{17} \mathrm{~F}_{3} \mathrm{~N}_{2} \mathrm{O}_{4}$ (406.36): C: 59.11, $\mathrm{H}: 4.22, \mathrm{~N}: 6.89$; found C: 59.19, H: 4.38, N: 6.95 .

2-(2,5-Dioxopyrrolidin-1-yl)- $N$-phenethyl-2-phenylacetamide (25)

White solid, yield: $73.5 \%$ (0.74 g); m.p. $138.4-139.2^{\circ} \mathrm{C}$; TLC: $\mathrm{R}_{\mathrm{f}}=0.4\left(\mathrm{~S}_{2}\right)$; UPLC (purity 99.0\%): $t_{\mathrm{R}}=5.57$ min. LC-MS (ESI): $m / z$ calculated for $\mathrm{C}_{20} \mathrm{H}_{20} \mathrm{~N}_{2} \mathrm{O}_{3}(\mathrm{M}+\mathrm{H})^{+} 337.15$, found 337.2. ${ }^{1} \mathrm{H}-\mathrm{NMR}$ $\left(500 \mathrm{MHz}, \mathrm{CDCl}_{3}\right) \delta 2.73\left(\mathrm{~s}, 4 \mathrm{H}\right.$, imide), $2.76\left(\mathrm{t}, J=6.8 \mathrm{~Hz}, 2 \mathrm{H}, \mathrm{CH}_{2}\right), 3.34-3.41\left(\mathrm{~m}, 1 \mathrm{H}, \mathrm{CH}_{2}\right), 3.60$ $\left(\mathrm{dd}, J=13.4,6.6 \mathrm{~Hz}, 1 \mathrm{H}, \mathrm{CH}_{2}\right), 5.59$ (br. s, $\left.1 \mathrm{H}, \mathrm{NH}\right), 5.63(\mathrm{~s}, 1 \mathrm{H}, \mathrm{CH}), 7.07-7.10(\mathrm{~m}, 2 \mathrm{H}, \mathrm{ArH})$, 7.15-7.20 (m, 1H, ArH), 7.20-7.29 (m, 3H, ArH), 7.30-7.33 (m, 2H, ArH), $7.44(\mathrm{~d}, J=6.7 \mathrm{~Hz}, 2 \mathrm{H}, \mathrm{ArH})$. ${ }^{13} \mathrm{C}-\mathrm{NMR}\left(126 \mathrm{MHz}, \mathrm{CDCl}_{3}\right)$ \& 28.3, 35.3, 41.4, 58.7, 126.6, 128.6, 128.7, 128.8, 128.9, 129.4, 129.8, 134.3, 138.6, 166.6, 176.6. Analysis calculated for $\mathrm{C}_{20} \mathrm{H}_{20} \mathrm{~N}_{2} \mathrm{O}_{3}$ (336.39): C: $71.41, \mathrm{H}: 5.99, \mathrm{~N}: 8.33$; found C: 71.29, H: 5.87, N: 8.49.

\section{2-(2,5-Dioxopyrrolidin-1-yl)-N-(2-fluorophenethyl)-2-phenylacetamide (26)}

White solid, yield: $69.8 \%$ (0.73 g); m.p. $142.4-142.8^{\circ} \mathrm{C}$; TLC: $\mathrm{R}_{\mathrm{f}}=0.44\left(\mathrm{~S}_{2}\right)$; UPLC (purity $>99.9 \%$ ): $t_{\mathrm{R}}=5.66 \mathrm{~min}$. LC-MS (ESI): $\mathrm{m} / z$ calculated for $\mathrm{C}_{20} \mathrm{H}_{19} \mathrm{FN}_{2} \mathrm{O}_{3}(\mathrm{M}+\mathrm{H})^{+}$355.14, found 355.2. ${ }^{1} \mathrm{H}-\mathrm{NMR}$ $\left(500 \mathrm{MHz}, \mathrm{CDCl}_{3}\right) \delta 2.74$ (s, $4 \mathrm{H}$, imide), 2.77-2.81 (m, 1H, $\left.\mathrm{CH}_{2}\right), 2.82-2.87\left(\mathrm{~m}, 1 \mathrm{H}, \mathrm{CH}_{2}\right), 3.42(\mathrm{dd}$, $\left.J=13.7,6.8 \mathrm{~Hz}, 1 \mathrm{H}, \mathrm{CH}_{2}\right), 3.56\left(\mathrm{dd}, J=13.4,6.5 \mathrm{~Hz}, 1 \mathrm{H}, \mathrm{CH}_{2}\right), 5.63(\mathrm{~s}, 2 \mathrm{H}, \mathrm{NH}, \mathrm{CH}), 6.95(\mathrm{t}, J=8.8$ $\mathrm{Hz}, 1 \mathrm{H}, \mathrm{ArH}), 7.02(\mathrm{t}, J=7.3 \mathrm{~Hz}, 1 \mathrm{H}, \mathrm{ArH}), 7.13-7.18(\mathrm{~m}, 2 \mathrm{H}, \mathrm{ArH}), 7.30-7.34(\mathrm{~m}, 3 \mathrm{H}, \mathrm{ArH}), 7.46(\mathrm{~d}$, $J=6.2 \mathrm{~Hz}, 2 \mathrm{H}, \mathrm{ArH}) .{ }^{13} \mathrm{C}-\mathrm{NMR}\left(126 \mathrm{MHz}, \mathrm{CDCl}_{3}\right) \delta 28.3,28.9,40.2,58.7,115.4(\mathrm{~d}, J=22.3 \mathrm{~Hz}), 124.2(\mathrm{~d}$, $J=3.6 \mathrm{~Hz}), 125.5(\mathrm{~d}, J=15.7 \mathrm{~Hz}), 128.4(\mathrm{~d}, J=8.4 \mathrm{~Hz}), 129.4,129.4,129.9,131.4(\mathrm{~d}, J=4.8 \mathrm{~Hz}), 134.2$, $161.2(\mathrm{~d}, J=245.1 \mathrm{~Hz}), 166.7,176.6$. Analysis calculated for $\mathrm{C}_{20} \mathrm{H}_{19} \mathrm{FN}_{2} \mathrm{O}_{3}$ (354.38): C: 67.79, H: 5.40, N: 7.91; found C: 67.61, H: 5.51, N: 7.84.

N-(3-Chlorophenethyl)-2-(2,5-dioxopyrrolidin-1-yl)-2-phenylacetamide (27)

White solid, yield: $73.4 \%$ (0.82 g); mp. $137.4-138.2{ }^{\circ} \mathrm{C}$; TLC: $\mathrm{R}_{\mathrm{f}}=0.62\left(\mathrm{~S}_{2}\right)$; UPLC (purity $>99.9 \%$ ): $t_{\mathrm{R}}=6.20 \mathrm{~min}$. LC-MS (ESI): $\mathrm{m} / \mathrm{z}$ calculated for $\mathrm{C}_{20} \mathrm{H}_{19} \mathrm{ClN}_{2} \mathrm{O}_{3}(\mathrm{M}+\mathrm{H})^{+} 371.11$, found 371.4. ${ }^{1} \mathrm{H}-\mathrm{NMR}$ $\left(500 \mathrm{MHz}, \mathrm{CDCl}_{3}\right) \delta 2.73-2.77\left(\mathrm{~m}, 6 \mathrm{H}\right.$, imide, $\left.\mathrm{CH}_{2}\right), 3.29\left(\mathrm{td}, J=13.3,6.6 \mathrm{~Hz}, 1 \mathrm{H}, \mathrm{CH}_{2}\right), 3.63(\mathrm{dd}, J=13.5$, $\left.6.6 \mathrm{~Hz}, 1 \mathrm{H}, \mathrm{CH}_{2}\right), 5.57(\mathrm{t}, J=5.2 \mathrm{~Hz}, 1 \mathrm{H}, \mathrm{NH}), 5.63(\mathrm{~s}, 1 \mathrm{H}, \mathrm{CH}), 6.99-7.01(\mathrm{~m}, 1 \mathrm{H}, \mathrm{ArH}), 7.14-7.17$ (m, 3H, ArH), 7.32-7.34 (m, 3H, ArH), 7.44-7.47 (m, 2H, ArH). ${ }^{13} \mathrm{C}-\mathrm{NMR}\left(126 \mathrm{MHz}, \mathrm{CDCl}_{3}\right) \delta 28.3$, 35.1, 41.2, 58.7, 126.8, 127.1, 129.2, 129.4, 129.5, 129.7, 129.9, 134.2, 134.4, 140.8, 166.7, 176.6. Analysis calculated for $\mathrm{C}_{20} \mathrm{H}_{19} \mathrm{ClN}_{2} \mathrm{O}_{3}$ (370.83): C: 64.78, $\mathrm{H}: 5.16, \mathrm{~N}: 7.55$; found C: 64.99, H: 5.05, N: 7.81 . 
$\mathrm{N}$-(4-Chlorophenethyl)-2-(2,5-dioxopyrrolidin-1-yl)-2-phenylacetamide (28)

White solid, yield: $68.6 \%$ (0.76 g); m.p. $137.2-137.8^{\circ} \mathrm{C}$; TLC: $\mathrm{R}_{\mathrm{f}}=0.52\left(\mathrm{~S}_{2}\right)$; UPLC (purity $>99.9 \%$ ): $t_{\mathrm{R}}=6.10 \mathrm{~min}$. LC-MS (ESI): $\mathrm{m} / z$ calculated for $\mathrm{C}_{20} \mathrm{H}_{19} \mathrm{ClN}_{2} \mathrm{O}_{3}(\mathrm{M}+\mathrm{H})^{+} 371.11$, found 371.4. ${ }^{1} \mathrm{H}-\mathrm{NMR}$ $\left(500 \mathrm{MHz}, \mathrm{CDCl}_{3}\right) \delta 2.72-2.76\left(\mathrm{~m}, 6 \mathrm{H}\right.$, imide, $\left.\mathrm{CH}_{2}\right), 3.31\left(\mathrm{dd}, J=13.2,5.7 \mathrm{~Hz}, 1 \mathrm{H}, \mathrm{CH}_{2}\right), 3.59(\mathrm{dd}$, $\left.J=13.2,6.3 \mathrm{~Hz}, 1 \mathrm{H}, \mathrm{CH}_{2}\right), 5.56(\mathrm{t}, J=5.2 \mathrm{~Hz}, 1 \mathrm{H}, \mathrm{NH}), 5.62(\mathrm{~s}, 1 \mathrm{H}, \mathrm{CH}), 7.02-7.05(\mathrm{~m}, 2 \mathrm{H}, \mathrm{Ar}), 7.18-7.20$ $(\mathrm{m}, 2 \mathrm{H}, \mathrm{ArH}), 7.29-7.35(\mathrm{~m}, 3 \mathrm{H}, \mathrm{ArH}), 7.42(\mathrm{~d}, J=6.8 \mathrm{~Hz}, 2 \mathrm{H}, \mathrm{ArH}) .{ }^{13} \mathrm{C}-\mathrm{NMR}\left(126 \mathrm{MHz}, \mathrm{CDCl}_{3}\right) \delta$ 28.3, 34.7, 41.2, 58.7, 128.8, 129.4, 129.4, 129.8, 130.2, 132.4, 134.2, 137.1, 166.6, 176.6. Analysis calculated for $\mathrm{C}_{20} \mathrm{H}_{19} \mathrm{ClN}_{2} \mathrm{O}_{3}$ (370.83): C: 64.78, H: 5.16, N: 7.55; found C: 64.53, H: 5.39, N: 7.72.

2-(2,5-Dioxopyrrolidin-1-yl)-2-phenyl- $N$-(3-(trifluoromethyl)phenethyl)acetamide (29)

White solid, yield: $69.3 \%\left(0.80\right.$ g); m.p. $149.2-150.4{ }^{\circ} \mathrm{C}$; TLC: $\mathrm{R}_{\mathrm{f}}=0.58\left(\mathrm{~S}_{2}\right)$; UPLC (purity $>99.9 \%$ ): $t_{\mathrm{R}}=6.92 \mathrm{~min}$. LC-MS (ESI): $\mathrm{m} / z$ calculated for $\mathrm{C}_{21} \mathrm{H}_{19} \mathrm{~F}_{3} \mathrm{~N}_{2} \mathrm{O}_{3}(\mathrm{M}+\mathrm{H})^{+}$405.14, found 405.3. ${ }^{1} \mathrm{H}-\mathrm{NMR}$ $\left(500 \mathrm{MHz}, \mathrm{CDCl}_{3}\right) \delta 2.75\left(\mathrm{~s}, 4 \mathrm{H}\right.$, imide) $2.81-2.89\left(\mathrm{~m}, 2 \mathrm{H}, \mathrm{CH}_{2}\right) 3.29-3.38\left(\mathrm{~m}, 1 \mathrm{H}, \mathrm{CH}_{2}\right) 3.66(\mathrm{dd}, J=13.5$, $\left.6.6 \mathrm{~Hz}, 1 \mathrm{H}, \mathrm{CH}_{2}\right) 5.59$ (br. s, $\left.1 \mathrm{H}, \mathrm{NH}\right) 5.63(\mathrm{~s}, 1 \mathrm{H}, \mathrm{CH}) 7.28-7.33(\mathrm{~m}, 3 \mathrm{H}, \mathrm{ArH}) 7.33-7.39(\mathrm{~m}, 2 \mathrm{H}, \mathrm{ArH})$ 7.41-7.47 (m, $4 \mathrm{H}, \mathrm{ArH}) .{ }^{13} \mathrm{C}-\mathrm{NMR}\left(126 \mathrm{MHz}, \mathrm{CDCl}_{3}\right) \delta 28.3,35.2,41.3,58.7,124.15(\mathrm{q}, J=272.2 \mathrm{~Hz})$, $123.5(\mathrm{q}, J=3.6 \mathrm{~Hz}), 125.7(\mathrm{q}, J=3.6 \mathrm{~Hz}), 129.1,129.4,129.5,129.7,130.1(\mathrm{q}, J=32.0 \mathrm{~Hz}), 132.4,134.2$, 139.8, 166.8 176.6. Analysis calculated for $\mathrm{C}_{21} \mathrm{H}_{19} \mathrm{~F}_{3} \mathrm{~N}_{2} \mathrm{O}_{3}$ (404.39): C: 62.37, $\mathrm{H}: 4.74, \mathrm{~N}: 6.93$, found C: 62.22, H: 4.66, N: 7.02.

\section{2-(2,5-Dioxopyrrolidin-1-yl)-2-phenyl- $N$-(3-(trifluoromethoxy)phenethyl)acetamide (30)}

White solid, yield: $64.3 \%$ (0.81 g); m.p. $113.3-114.2{ }^{\circ} \mathrm{C}$; TLC: $\mathrm{R}_{\mathrm{f}}=0.62\left(\mathrm{~S}_{2}\right)$; UPLC (purity $>99.9 \%$ ): $t_{\mathrm{R}}=6.64$ min. LC-MS (ESI): $\mathrm{m} / z$ calculated for $\mathrm{C}_{21} \mathrm{H}_{19} \mathrm{~F}_{3} \mathrm{~N}_{2} \mathrm{O}_{4}(\mathrm{M}+\mathrm{H})^{+} 421.13$, found 421.1. ${ }^{1} \mathrm{H}-\mathrm{NMR}$ $\left(500 \mathrm{MHz}, \mathrm{CDCl}_{3}\right) \delta 2.75(\mathrm{~s}, 4 \mathrm{H}), 2.80\left(\mathrm{t}, J=6.9 \mathrm{~Hz}, 2 \mathrm{H}, \mathrm{CH}_{2}\right), 3.30-3.38\left(\mathrm{~m}, 1 \mathrm{H}, \mathrm{CH}_{2}\right), 3.63(\mathrm{dd}, J=13.5$, $\left.6.6 \mathrm{~Hz}, 1 \mathrm{H}, \mathrm{CH}_{2}\right), 5.59(\mathrm{t}, J=5.4 \mathrm{~Hz}, 1 \mathrm{H}, \mathrm{NH}), 5.64(\mathrm{~s}, 1 \mathrm{H}, \mathrm{CH}), 6.99(\mathrm{~s}, 1 \mathrm{H}, \mathrm{ArH}), 7.03-7.07(\mathrm{~m}, 2 \mathrm{H}, \mathrm{ArH})$, 7.25-7.34 (m, 4H, ArH), $7.45(\mathrm{~d}, J=6.6 \mathrm{~Hz}, 2 \mathrm{H}, \mathrm{ArH}) .{ }^{13} \mathrm{C}-\mathrm{NMR}\left(126 \mathrm{MHz}, \mathrm{CDCl}_{3}\right) \delta 28.3,35.1,41.2$, $58.7,120.2(\mathrm{~d}, J=309.6 \mathrm{~Hz}), 120.5(\mathrm{~d}, J=256.5 \mathrm{~Hz}), 127.3,129.4,129.7(\mathrm{t}, J=31.1 \mathrm{~Hz}), 134.2,141.1,149.5$, 166.7, 176.6. Analysis calculated for $\mathrm{C}_{21} \mathrm{H}_{19} \mathrm{~F}_{3} \mathrm{~N}_{2} \mathrm{O}_{4}$ (420.39): C: 60.00, $\mathrm{H}: 4.56, \mathrm{~N}: 6.66$; found C: 60.21, H: $4.42, \mathrm{~N}: 6.48$.

2-(2,5-Dioxopyrrolidin-1-yl)-2-phenyl- $N$-(3-phenylpropyl)acetamide (31)

White solid, yield: $73.7 \%$ (0.77 g); m.p. $133.1-133.9{ }^{\circ} \mathrm{C}$; TLC: $\mathrm{R}_{\mathrm{f}}=0.50\left(\mathrm{~S}_{2}\right)$; UPLC (purity $>99.9 \%$ ): $t_{\mathrm{R}}=6.16 \mathrm{~min}$. LC-MS (ESI): $\mathrm{m} / z$ calculated for $\mathrm{C}_{21} \mathrm{H}_{22} \mathrm{~N}_{2} \mathrm{O}_{3}(\mathrm{M}+\mathrm{H})^{+}$351.16, found 351.2. ${ }^{1} \mathrm{H}-\mathrm{NMR}$ $\left(500 \mathrm{MHz}, \mathrm{CDCl}_{3}\right) \delta 1.78\left(\mathrm{td}, J=7.5,2.9 \mathrm{~Hz}, 2 \mathrm{H}, \mathrm{CH}_{2}\right), 2.58\left(\mathrm{t}, J=7.7 \mathrm{~Hz}, 2 \mathrm{H}, \mathrm{CH}_{2}\right), 2.74(\mathrm{~s}, 4 \mathrm{H}$, imide), 3.18-3.22 (m, 1H, $\left.\mathrm{CH}_{2}\right), 3.31-3.36\left(\mathrm{~m}, 1 \mathrm{H}, \mathrm{CH}_{2}\right), 5.55-5.63\left(\mathrm{~m}, 1 \mathrm{H}, \mathrm{CH}_{2}\right), 5.66(\mathrm{~s}, 1 \mathrm{H}, \mathrm{NH})$, 7.09-7.17 (m, 3H, ArH), 7.22-7.24 (m, 2H, ArH), 7.38-7.40 (m, 3H, ArH), 7.53-7.55 (m, 2H, ArH). ${ }^{13} \mathrm{C}-\mathrm{NMR}\left(126 \mathrm{MHz}, \mathrm{CDCl}_{3}\right) \delta$ 28.3, 31.0, 33.1, 39.7, 58.7, 126.1, 128.4, 128.5, 129.5, 129.9, 134.5, 141.3, 166.6, 176.6. Analysis calculated for $\mathrm{C}_{21} \mathrm{H}_{22} \mathrm{~N}_{2} \mathrm{O}_{3}$ (350.42): C: 71.98, $\mathrm{H}: 6.33, \mathrm{~N}: 7.99$; found C: 71.62, H: 6.28, N: 8.12.

\subsection{Anticonoulsant Activity}

Experiments were performed on adult male CD-1 mice weighing 22-26 g, purchased from the Animal House at the Faculty of Pharmacy, Jagiellonian University Medical College, Cracow, Poland. The animals were kept at room temperature of $20 \pm 2{ }^{\circ} \mathrm{C}$ under standard conditions. Initial qualitative efficacy screening was conducted in groups of four mice. To obtain the $\mathrm{ED}_{50}$ (median effective dose), at least three groups of six mice were injected with various doses of tested compounds. The anticonvulsant activity studies were approved by the Local Ethical Committee in Cracow, Poland (No 111/2016, 165/2018, 228A/2019, 360/2019) and conducted in compliance with the European Union Directive of 22 September 2010 (2010/63/EU). The tested substances were suspended in a 1\% solution of Tween-80 and administered via the intraperitoneal (i.p.) route in a volume of $10 \mathrm{~mL} / \mathrm{kg}$ body weight. 
LTG, and VPA were purchased in Sigma-Aldrich (St. Louis, MO, USA), LCS in UCB Pharma (Braine-1'Alleud, Belgium). The pretreatment times for the aforementioned reference AEDs were based on information from the National Institute of Neurological Disorders and Stroke (NINDS) Epilepsy Therapy Screening Program (ETSP) [38]. The in vivo procedures for the following tests are reported elsewhere: maximal electroshock seizure test (MES) [14], the $6 \mathrm{~Hz}(32 \mathrm{~mA})$ seizure model [14], and the rotarod test for acute neurological toxicity [9].

\subsection{Antinociceptive Activity}

The experimental groups consisted of 6-12 adult male Albino Swiss mice (CD-1, 18-25 g). Each animal was tested only once. Immediately after the assay, the animals were sacrificed by cervical dislocation. Behavioral measurements were observed by trained observers. The in vivo antinociceptive assays were in accordance with Polish regulations and European Union Directive of 22 September 2010 (2010/63/EU). All procedures were carried out according to the rules of the International Council on Laboratory Animal Science (ICLAS) and were approved by the Local Ethical Committee in Cracow, Poland (approval No 104/2015, 111/2016, and 179/2017). The tested substances were suspended in $1 \%$ aqueous solution of Tween-80 and were injected i.p. $30 \mathrm{~min}$ prior to the test. Control group animals (negative control) were administered with an appropriate amount of vehicle (Tween-80, $1 \%$ aqueous solution, i.p.) $30 \mathrm{~min}$ prior to the test.

The experimental in vivo procedures were previously reported for the formalin test [39]; compounds 4 and 30 were tested in three doses-40, 80, $120 \mathrm{mg} / \mathrm{kg}$ (4), and 20, 40, $80 \mathrm{mg} / \mathrm{kg}$ (30). Before formalin application, different groups of animals were injected i.p. with vehicle $(10 \mathrm{~mL} / \mathrm{kg}$, negative control). The in vivo procedure for the model of capsaicin-induced nociception was previously reported [40]; the animals were pretreated with vehicle $(10 \mathrm{~mL} / \mathrm{kg}$, negative control) and the dose-response of investigated compounds was evaluated at 40,80,120 mg/kg (4), and 20, $40,80 \mathrm{mg} / \mathrm{kg}$ (30). The in vivo procedure for the model of OXPT-induced peripheral neuropathy was previously reported [41]; the mice with developed tactile allodynia were pretreated i.p. with test compound $30(20,40$, and $80 \mathrm{mg} / \mathrm{kg})$ and vehicle.

\subsection{In Vivo Data Analysis}

\subsubsection{Anticonvulsant Activity and Neurotoxicity Studies}

The probit analysis [23] was used to calculate the $\mathrm{ED}_{50}$ and $\mathrm{TD}_{50}$ values with $95 \%$ confidence limits. The PI values (protective indexes) for the tested substance and standard AEDs were calculated by dividing the $\mathrm{TD}_{50}$ value, as determined in the rotarod test, by the respective $\mathrm{ED}_{50}$ value, as determined in the MES or $6 \mathrm{~Hz}(32 \mathrm{~mA})$ tests.

\subsubsection{Antinociceptive Activity Studies}

Data are presented as means \pm standard error of the mean (SEM). The GraphPad Prism Software (v.5) was used to analyze the vast majority of data. Statistically significant differences between groups were calculated using one-way analysis of variance (ANOVA) and the post hoc Dunnett's multiple comparison test or two-way analysis of variance (ANOVA). The criterion for significance was set at $p<0.05$. The log-probit method was applied to statistically determine the $\mathrm{ED}_{50}$ values with $95 \%$ confidence limits.

\subsection{In Vitro ADME-Tox Studies}

\subsubsection{Permeability}

Precoated PAMPA Plate System Gentest ${ }^{\mathrm{TM}}$ was provided by Corning, (Tewksbury, MA, USA). The detailed procedure and proper formulas were described previously [36]. 


\subsubsection{Metabolic Stability}

These assays were performed on human liver microsomes (HLMs), purchased from Sigma-Aldrich (St. Louis, MO, USA), according to [14].

3.5.3. Influence on Recombinant Human CYP3A4, CYP2D6, and CYP2C9 Cytochrome P450 Isoforms

The luminescent CYP3A4 P450-Glo ${ }^{\mathrm{TM}}$, CYP2D6 P450-Glo ${ }^{\mathrm{TM}}$, and CYP2C9 P450-Glo ${ }^{\mathrm{TM}}$ assays and protocols were provided by Promega (Madison, WI, USA) [42]. The detailed procedures are reported in the literature (CYP3A4 [14,15], CYP2D6 [15], and CYP2C9 [36]).

\subsubsection{Hepatotoxicity Assessment}

These studies were performed on hepatoma HepG2 cells, according to a protocol reported previously [43]

\subsection{In Silico Studies}

The biotransformation pathways for metabolites 2, 24, and 30 were estimated in silico by MetaSite 6.0.1 provided by Molecular Discovery Ltd. (Hertfordshire, UK). The metabolic pathways and probable metabolite structures were studied using a liver computational model [44].

\subsection{In Vitro Binding and Functional Assays}

Binding studies were carried out commercially in Eurofines Laboratories (Poitiers, France). The functional assays were performed in Eurofins Panlabs Discovery Services Taiwan, Ltd. (New Taipei City, Taiwan). All procedures are described elsewhere (for details, see Table S4 in Supplementary Materials).

\section{Conclusions}

In the current studies, we developed a new series of hybrid anticonvulsants with an incorporated phenylglycine moiety. These compounds were designed as analogues or previously reported alanine derivatives which showed broad-spectrum and potent anticonvulsant efficacy. As a result, several compounds described herein revealed potent protection in the maximal electroshock (MES) test and the psychomotor $6 \mathrm{~Hz}(32 \mathrm{~mA})$ seizure model in mice, which are recognized as the standard and widely applied seizure models for early identification of new AED candidates. The most potent anticonvulsant activity and satisfactory safety profile were demonstrated for compound $\mathbf{3 0}$. In addition, $\mathbf{3 0}$ was effective in the formalin test of tonic pain, the capsaicin-induced pain model, and the oxaliplatin-induced neuropathic pain model in mice. The plausible mechanism of action of $\mathbf{3 0}$ is probably related to the inhibition of calcium currents mediated by $\mathrm{Cav}_{1.2}$ (L-type) channels. Notably, 30 revealed high metabolic stability on human liver microsomes, negligible hepatotoxicity, and relatively weak inhibition of cytochrome P450 isoenzymes. In conclusion, compound 30 seems to be worthy of further and more detailed characterization as a potential candidate for the treatment of epilepsy and neuropathic pain.

Supplementary Materials: Supplementary Materials can be found at http://www.mdpi.com/1422-0067/21/22/ 8780/s1. General procedure for the preparation staring amine derivatives (A1 and A2); Table S1. Anticonvulsant activity and acute neurotoxicity screening data in the MES, $6 \mathrm{~Hz}(32 \mathrm{~mA})$, and rotarod tests in mice i.p. (dose of $100 \mathrm{mg} / \mathrm{kg}$ ) - compounds 3-13; Table S2. Anticonvulsant activity and acute neurotoxicity screening data in the MES, $6 \mathrm{~Hz}(32 \mathrm{~mA})$, and rotarod tests in mice i.p. (dose of $100 \mathrm{mg} / \mathrm{kg}$ ) - compounds 14-24; Table S3. Anticonvulsant activity and acute neurotoxicity screening data in the MES, $6 \mathrm{~Hz}(32 \mathrm{~mA})$, and rotarod tests in mice i.p. (dose of $100 \mathrm{mg} / \mathrm{kg}$ ) — compounds 25-31; Table S4. In vitro binding and functional assays; Figure S1. UPLC chromatogram after 120 min incubation of compound 4 with HLMs; Figure S2. MS ion fragment analyses and most probable structures of compound 4 metabolites M1-M3; Figure S3. UPLC chromatogram after 120 min incubation of compound 24 with HLMs; Figure S4. MS ion fragment analyses and most probable structure of 24 metabolite M1; Figure S5. UPLC chromatogram after $120 \mathrm{~min}$ incubation of compound 30 with HLMs; Figure S6. MS ion fragment analyses and most probable structures of 30 metabolites M1 and M2; Figure S7. The MetaSite 
6.0.1. software predictions of the most probably sites of compounds 4, 24, and 30 metabolism; ${ }^{1} \mathrm{H}-\mathrm{NMR}$ and ${ }^{13} \mathrm{C}-\mathrm{NMR}$ spectra for selected final compounds.

Author Contributions: Conceptualization, K.K.; formal analysis, R.M.K.; funding acquisition, K.K.; investigation, M.A., M.J., A.R., S.M., and G.L.; methodology, M.A., M.J., A.R., S.M., and G.L.; project administration, K.K.; supervision, K.K.; writing-original draft, M.A., M.J., A.R., S.M., G.L., R.M.K., and K.K.; writing-review and editing, R.M.K. and K.K. All authors read and agreed to the published version of the manuscript.

Funding: The studies were supported by the National Science Center, Poland grant UMO-2015/18/E/NZ7/00509.

Conflicts of Interest: The authors declare no conflict of interest. The funder had no role in the design of the study; in the collection, analyses, or interpretation of data; in the writing of the manuscript, or in the decision to publish the results.

\section{Abbreviations}

$\begin{array}{ll}\text { ADME-Tox } & \text { Absorption, distribution, metabolism, excretion, toxicity } \\ \text { AEDs } & \text { Antiepileptic drugs } \\ \text { CCCP } & \text { 3-Chlorophenylhydrazone } \\ \text { CDI } & \text { Carbonyldiimidazole } \\ \text { CFN } & \text { Caffeine } \\ \text { CNS } & \text { Central nervous system } \\ \text { DCM } & \text { Dichloromethane } \\ \text { DMF } & \text { Dimethylformamide } \\ \text { DX } & \text { Doxorubicin } \\ \text { HLMs } & \text { Human liver microsomes } \\ \text { HMDS } & \text { Hexamethyldisilazane } \\ 6 \text { Hz } & \text { 6 Hz seizure test } \\ \text { KE } & \text { Ketoconazole } \\ \text { LCS } & \text { Lacosamide } \\ \text { LiAlH } 4 & \text { Lithium aluminum hydride } \\ \text { LTG } & \text { Lamotrigine } \\ \text { Lacosamide } & \text { Acetonitrile } \\ \text { MES } & \text { Maximal electroshock seizure test } \\ \text { MeOH } & \text { Methanol } \\ \text { NFX } & \text { Norfloxacin } \\ \text { OXPT } & \text { Oxaliplatin } \\ \text { PAMPA } & \text { Parallel artificial membrane permeability assay } \\ \text { PI } & \text { Protective index (TD } 50 / \text { ED } 50 \\ \text { QD } & \text { Quinidine } \\ \text { SE } & \text { Sulfaphenazole } \\ \text { THF } & \text { Tetrahydrofuran } \\ \text { TPE } & \text { Time of peak effect } \\ \text { VPA } & \text { Valproic acid } \\ & \end{array}$

\section{References}

1. Golyala, A.; Kwan, P. Drug development for refractory epilepsy: The past 25 years and beyond. Seizure 2017, 44, 147-156. [CrossRef] [PubMed]

2. World Health Organization. Media Centre. Epilepsy. Fact Sheet No. 999. May 2015. Available online: http://www.who.int/mediacentre/factsheets/fs999/en/ (accessed on 19 November 2020).

3. Tang, F.; Hartz, A.M.S.; Bauer, B. Drug-Resistant Epilepsy: Multiple Hypotheses, Few Answers. Front. Neurol. 2017, 8, 301. [CrossRef] [PubMed]

4. Salpekar, J.A.; Mula, M. Common psychiatric comorbidities in epilepsy: How big of a problem is it? Epilepsy Behav. 2019, 98, 293-297. [CrossRef] [PubMed]

5. Löscher, W.; Klitgaard, H.; Twyman, R.E.; Schmidt, D. New avenues for anti-epileptic drug discovery and development. Nat. Rev. Drug Discov. 2013, 12, 757-776. [CrossRef] 
6. Petrelli, A.; Valabrega, G. Multitarget drugs: The present and the future of cancer therapy. Expert Opin. Pharmacother. 2009, 10, 589-600. [CrossRef]

7. Youdim, M.B.H.; Kupershmidt, L.; Amit, T.; Weinreb, O. Promises of novel multi-target neuroprotective and neurorestorative drugs for Parkinson's disease. Parkinsonism Relat. Disord. 2014, 20, S132-S136. [CrossRef]

8. Simone Tranches Dias, K.; Viegas, C. Multi-Target Directed Drugs: A Modern Approach for Design of New Drugs for the treatment of Alzheimer's Disease. Curr. Neuropharmacol. 2014, 12, 239-255. [CrossRef]

9. Abram, M.; Zagaja, M.; Mogilski, S.; Andres-Mach, M.; Latacz, G.; Baś, S.; Łuszczki, J.J.; Kieć-Kononowicz, K.; Kamiński, K. Multifunctional Hybrid Compounds Derived from 2-(2,5-Dioxopyrrolidin-1-yl)-3-methoxypropanamides with Anticonvulsant and Antinociceptive Properties. J. Med. Chem. 2017, 60, 8565-8579. [CrossRef]

10. Talevi, A. Multi-target pharmacology: Possibilities and limitations of the "skeleton key approach" from a medicinal chemist perspective. Front. Pharmacol. 2015, 6, 205. [CrossRef]

11. Bansal, Y.; Silakari, O. Multifunctional compounds: Smart molecules for multifactorial diseases. Eur. J. Med. Chem. 2014, 76, 31-42. [CrossRef]

12. Kamiński, K.; Rapacz, A.; Łuszczki, J.J.; Latacz, G.; Obniska, J.; Kieć-Kononowicz, K.; Filipek, B. Design, synthesis and biological evaluation of new hybrid anticonvulsants derived from $\mathrm{N}$-benzyl-2-(2,5-dioxopyrrolidin-1-yl)propanamide and 2-(2,5-dioxopyrrolidin-1-yl)butanamide derivatives. Bioorg. Med. Chem. 2015, 23, 2548-2561. [CrossRef] [PubMed]

13. Kamiński, K.; Rapacz, A.; Filipek, B.; Obniska, J. Design, synthesis and anticonvulsant activity of new hybrid compounds derived from $N$-phenyl-2-(2,5-dioxopyrrolidin-1-yl)-propanamides and -butanamides. Bioorg. Med. Chem. 2016, 24, 2938-2946. [CrossRef] [PubMed]

14. Kamiński, K.; Zagaja, M.; Łuszczki, J.J.; Rapacz, A.; Andres-Mach, M.; Latacz, G.; Kieć-Kononowicz, K. Design, Synthesis, and Anticonvulsant Activity of New Hybrid Compounds Derived from 2-(2,5-Dioxopyrrolidin-1-yl)propanamides and 2-(2,5-Dioxopyrrolidin-1-yl)butanamides. J. Med. Chem. 2015, 58, 5274-5286. [CrossRef] [PubMed]

15. Abram, M.; Rapacz, A.; Mogilski, S.; Latacz, G.; Lubelska, A.; Kamiński, R.M.; Kamiński, K. Multitargeted Compounds Derived from (2,5-Dioxopyrrolidin-1-yl)(phenyl)-Acetamides as Candidates for Effective Anticonvulsant and Antinociceptive Agents. ACS Chem. Neurosci. 2020, 11, 1996-2008. [CrossRef]

16. Mäkinen, J.; Rainesalo, S.; Raitanen, J.; Peltola, J. The effect of newer antiepileptic drugs in combination therapy. Epilepsy Res. 2017, 132, 15-20. [CrossRef]

17. Castel-Branco, M.M.; Alves, G.L.; Figueiredo, I.V.; Falcão, A.; Caramona, M.M. The maximal electroshock seizure (MES) model in the preclinical assessment of potential new antiepileptic drugs. Methods Find. Exp. Clin. Pharmacol. 2009. [CrossRef]

18. Reddy, P.Y.; Kondo, S.; Toru, T.; Ueno, Y. Lewis Acid and Hexamethyldisilazane-Promoted Efficient Synthesis of N-Alkyl- and N-Arylimide Derivatives. J. Org. Chem. 1997, 62, 2652-2654. [CrossRef]

19. Galanopoulou, A.S.; Kokaia, M.; Loeb, J.A.; Nehlig, A.; Pitkänen, A.; Rogawski, M.A.; Staley, K.J.; Whittemore, V.H.; Dudek, F.E. Epilepsy therapy development: Technical and methodologic issues in studies with animal models. Epilepsia 2013, 54, 13-23. [CrossRef]

20. Bialer, M.; White, H.S. Key factors in the discovery and development of new antiepileptic drugs. Nat. Rev. Drug Discov. 2010, 9, 68-82. [CrossRef]

21. Barton, M.E.; Klein, B.D.; Wolf, H.H.; Steve White, H. Pharmacological characterization of the $6 \mathrm{~Hz}$ psychomotor seizure model of partial epilepsy. Epilepsy Res. 2001, 47, 217-227. [CrossRef]

22. Romoli, M.; Mazzocchetti, P.; D'Alonzo, R.; Siliquini, S.; Rinaldi, V.E.; Verrotti, A.; Calabresi, P.; Costa, C. Valproic Acid and Epilepsy: From Molecular Mechanisms to Clinical Evidences. Curr. Neuropharmacol. 2019, 17, 926-946. [CrossRef] [PubMed]

23. Litchfield, J.T.; Wilcoxon, F.A. Simplified Method of Evaluating Dose-Effect Experiments. J. Pharmacol. Exp. Ther. 1949, 96, 99-113. [PubMed]

24. Salinas-Abarca, A.B.; Avila-Rojas, S.H.; Barragán-Iglesias, P.; Pineda-Farias, J.B.; Granados-Soto, V. Formalin injection produces long-lasting hypersensitivity with characteristics of neuropathic pain. Eur. J. Pharmacol. 2017, 797, 83-93. [CrossRef] [PubMed]

25. Muley, M.M.; Krustev, E.; McDougall, J.J. Preclinical Assessment of Inflammatory Pain. CNS Neurosci. Ther. 2016, 22, 88-101. [CrossRef] [PubMed] 
26. Laughlin, T.M.; Tram, K.V.; Wilcox, G.L.; Birnbaum, A.K. Comparison of Antiepileptic Drugs Tiagabine, Lamotrigine, and Gabapentin in Mouse Models of Acute, Prolonged, and Chronic Nociception. J. Pharmacol. Exp. Ther. 2002, 302, 1168-1175. [CrossRef]

27. Yashpal, K.; Fisher, K.; Chabot, J.-G.; Coderre, T.J. Differential effects of NMDA and group I mGluR antagonists on both nociception and spinal cord protein kinase $C$ translocation in the formalin test and a model of neuropathic pain in rats. Pain 2001, 94, 17-29. [CrossRef]

28. Descoeur, J.; Pereira, V.; Pizzoccaro, A.; Francois, A.; Ling, B.; Maffre, V.; Couette, B.; Busserolles, J.; Courteix, C.; Noel, J.; et al. Oxaliplatin-induced cold hypersensitivity is due to remodelling of ion channel expression in nociceptors. EMBO Mol. Med. 2011, 3, 266-278. [CrossRef]

29. Roca-Lapirot, O.; Radwani, H.; Aby, F.; Nagy, F.; Landry, M.; Fossat, P. Calcium signalling through L-type calcium channels: Role in pathophysiology of spinal nociceptive transmission. Br. J. Pharmacol. 2018, 175, 2362-2374. [CrossRef]

30. Radwani, H.; Lopez-Gonzalez, M.J.; Cattaert, D.; Roca-Lapirot, O.; Dobremez, E.; Bouali-Benazzouz, R.; Eiríksdóttir, E.; Langel, Ü.; Favereaux, A.; Errami, M.; et al. Cav1.2 and Cav1.3 L-type calcium channels independently control short- and long-term sensitization to pain. J. Physiol. 2016, 594, 6607-6626. [CrossRef]

31. Yaksh, T.L. Calcium Channels as Therapeutic Targets in Neuropathic Pain. J. Pain 2006, 7, S13-S30. [CrossRef]

32. Perucca, E.; Meador, K.J. Adverse effects of antiepileptic drugs. Acta Neurol. Scand. 2005, 112, 30-35. [CrossRef] [PubMed]

33. Bergmann, K.R.; Broekhuizen, K.; Groeneveld, G.J. Clinical trial simulations of the interaction between cannabidiol and clobazam and effect on drop-seizure frequency. Br. J. Clin. Pharmacol. 2020, 86, 380-385. [CrossRef] [PubMed]

34. Handoko, K.B.; Souverein, P.C.; Staa, T.P.V.; Meyboom, R.H.B.; Leufkens, H.G.M.; Egberts, T.C.G.; Bemt, P.M.L.A.V. Risk of Aplastic Anemia in Patients Using Antiepileptic Drugs. Epilepsia 2006, 47, 1232-1236. [CrossRef]

35. Phillips, K.A.; Veenstra, D.L.; Oren, E.; Lee, J.K.; Sadee, W. Potential Role of Pharmacogenomics in Reducing Adverse Drug Reactions: A Systematic Review. JAMA 2001, 286, 2270-2279. [CrossRef] [PubMed]

36. Kamiński, K.; Socała, K.; Zagaja, M.; Andres-Mach, M.; Abram, M.; Jakubiec, M.; Pieróg, M.; Nieoczym, D.; Rapacz, A.; Gawel, K.; et al. N-Benzyl-(2,5-dioxopyrrolidin-1-yl)propanamide (AS-1) with Hybrid Structure as a Candidate for a Broad-Spectrum Antiepileptic Drug. Neurotherapeutics 2020, 17, 309-328. [CrossRef] [PubMed]

37. Kamiński, K.; Mogilski, S.; Abram, M.; Rapacz, A.; Latacz, G.; Szulczyk, B.; Walczak, M.; Kuś, K.; Matyjaszczyk, K.; Kamiński, R.M. KA-104, a new multitargeted anticonvulsant with potent antinociceptive activity in preclinical models. Epilepsia 2020, 61, 2119-2128. [CrossRef]

38. Kehne, J.H.; Klein, B.D.; Raeissi, S.; Sharma, S. The National Institute of Neurological Disorders and Stroke (NINDS) Epilepsy Therapy Screening Program (ETSP). Neurochem. Res. 2017, 42, 1894-1903. [CrossRef]

39. Beirith, A.; Santos, A.R.S.; Rodrigues, A.L.S.; Creczynski-Pasa, T.B.; Calixto, J.B. Spinal and supraspinal antinociceptive action of dipyrone in formalin, capsaicin and glutamate tests. Study of the mechanism of action. Eur. J. Pharmacol. 1998, 345, 233-245. [CrossRef]

40. Mogilski, S.; Kubacka, M.; Redzicka, A.; Kazek, G.; Dudek, M.; Malinka, W.; Filipek, B. Antinociceptive, anti-inflammatory and smooth muscle relaxant activities of the pyrrolo[3,4-d]pyridazinone derivatives: Possible mechanisms of action. Pharmacol. Biochem. Behav. 2015, 133, 99-110. [CrossRef]

41. Sałat, K.; Cios, A.; Wyska, E.; Sałat, R.; Mogilski, S.; Filipek, B.; Więckowski, K.; Malawska, B. Antiallodynic and antihyperalgesic activity of 3-[4-(3-trifluoromethyl-phenyl)-piperazin-1-yl]-dihydrofuran-2-one compared to pregabalin in chemotherapy-induced neuropathic pain in mice. Pharmacol. Biochem. Behav. 2014, 122, 173-181. [CrossRef]

42. Cali, J.J.; Ma, D.; Sobol, M.; Simpson, D.J.; Frackman, S.; Good, T.D.; Daily, W.J.; Liu, D. Luminogenic cytochrome P450 assays. Expert Opin. Drug Metab. Toxicol. 2006, 2, 629-645. [CrossRef] [PubMed] 
43. Socała, K.; Mogilski, S.; Pieróg, M.; Nieoczym, D.; Abram, M.; Szulczyk, B.; Lubelska, A.; Latacz, G.; Doboszewska, U.; Wlaź, P.; et al. KA-11, a Novel Pyrrolidine-2,5-dione Derived Broad-Spectrum Anticonvulsant: Its Antiepileptogenic, Antinociceptive Properties and in Vitro Characterization. ACS Chem. Neurosci. 2019, 10, 636-648. [CrossRef] [PubMed]

44. Cruciani, G.; Carosati, E.; De Boeck, B.; Ethirajulu, K.; Mackie, C.; Howe, T.; Vianello, R. MetaSite: Understanding Metabolism in Human Cytochromes from the Perspective of the Chemist. J. Med. Chem. 2005, 48, 6970-6979. [CrossRef] [PubMed]

Publisher's Note: MDPI stays neutral with regard to jurisdictional claims in published maps and institutional affiliations.

(C) 2020 by the authors. Licensee MDPI, Basel, Switzerland. This article is an open access article distributed under the terms and conditions of the Creative Commons Attribution (CC BY) license (http://creativecommons.org/licenses/by/4.0/). 